\title{
How Skilled Migrants Enter and Stay in the U.S. Labor Market
}

\section{Elizabeth M. Jacobs ${ }^{1}$}

${ }^{1}$ Massive Data Institute and Institute for the Study of International Migration, McCourt School of Public Policy, Georgetown University, Washington, D.C. USA

\section{*Correspondence:}

Elizabeth Jacobs

elizabeth.jacobs@georgetown.edu

Keywords: labor migration; foreign credentials; labor market incorporation; institutions 


\begin{abstract}
This paper examines how academic, corporate and state institutions shape inequality in the flow and labor market incorporation of skilled migrants. Using two original datasets, the paper finds that where a migrant earns their degree matters more for explaining patterns of migration and employment than how many degrees they hold, challenging standard theories of human capital and migration.

Logistic regression analysis of a novel dataset of LinkedIn employment histories shows that migrants with U.S. degrees are more likely to work in the U.S. at first and current job, while foreign advanced degrees have a strong negative effect on U.S. employment. 105 in-depth interviews show that U.S. universities facilitate the school-to-work transition to the U.S. labor market for international students and U.S. companies display preferences for U.S. degrees.

The paper develops new data sources to study dynamic migration flows in transnational, longitudinal perspective and analyzes these data through a multi-level framework that situates migration and employment within institutional contexts driving inequality in labor market outcomes. The findings emphasize the importance of analyzing the effect country of education and level of educational attainment in shaping labor migration flows. I offer a new conceptualization of life-course transitions in the global education and labor markets as migration decisions.
\end{abstract}


The scale and complexity of global skilled migration has intensified as highly educated migrants engage in new spatial and temporal migration patterns across the life-course. Not only is the growth rate of global skilled migration more than three times that of less-skilled migrants, but migrants with advanced skills and knowledge are moving from a more diverse set of sending countries to a more diverse set of receiving countries, and are moving in dynamic and non-linear migration patterns for more varied amounts of time (Feliciano 2005; Kerr et al. 2016). Migrants might settle permanently abroad, return to their country of origin with new expertise and experience developed overseas, or divvy their time between multiple destinations in patterns of circular migration.

This paper offers two contributions - one methodological and one theoretical - to the research on migration and the life-course. First, it develops new data sources to study dynamic migration flows across the life-course in transnational, longitudinal perspective, addressing temporal and spatial issues common in many cross-sectional and national-level survey datasets. Second, it advances a multi-level framework that situates migrant decision-making within institutional contexts that enable and constrain those choices. At the individual level, the theoretical model proposes that initial migration decisions affect subsequent choices; at the institutional level, the model develops interlinkages between universities, companies and the state, and how together they structure, enable and constrain migration pathways in and out of the United States.

Corporate and academic institutions function as migration gatekeepers as they create opportunities for migrants to study and work in a foreign country on student and work visas, highlighting their central role in the immigration system (Kato and Sparber 2013; Kerr et al. 2016). These institutions work in tandem and in opposition in shaping the flow of skilled 
migration, yet research on skilled migration has not yet fully theorized the interconnections between global educational and labor market institutions, nor sufficiently studied the opportunities and constraints that institutions present at different points across the migrant lifecourse. To examine how these institutional interlinkages affect skilled migration and U.S. employment through an empirical lens, this paper asks, how does country of education shape migrant trajectories in entering and staying in the U.S. labor market?

The empirical analysis draws on a unique combination of 7,177 employment histories and 105 in-depth interviews with skilled migrants and institutional actors at companies, universities and the immigration system. Leveraging the transnational and longitudinal nature of a novel dataset of migrant employment histories that I developed from LinkedIn profiles, I use ordinary least squares (OLS) linear probability models and binary logistic regression to analyze predictors of settlement and return among skilled migrants across the life course. I then analyze interview data with skilled migrants and institutional administrators to examine distinct institutional pathways into the U.S. labor market through U.S. university/company collaborations, multinational corporations, and Indian-based subcontracting companies.

I find that a migrant's country of education has a powerful effect in determining how they enter the United States and whether they settle permanently or return to India. Multivariable regression analysis of education and employment histories shows that a U.S. education is a strong positive predictor of entering the U.S. labor market after graduation, and staying in the U.S. labor market long-term. Conversely, an Indian education is a negative predictor of U.S. employment at first job and current job. Counter to standard theories of human capital and global migration that would suggest more education leads to skilled migration and settlement, higher levels of Indian educational attainment have a strong negative effect on current U.S. 
employment. In other words, these results suggest that where a migrant earns their degree matters more in shaping skilled labor migration than how many degrees they earn.

In-depth interviews with skilled migrants and university and company administrators provide context for the mechanisms driving this effect of a U.S. education. Results show that U.S. universities facilitate the school-to-work transition in the U.S. labor market for international students by collaborating with companies and providing strategies for satisfying U.S. work authorization requirements. Further, U.S. companies display a hiring preference for U.S. university graduates over those with Indian degrees through social networks and credential evaluation.

These findings have important implications for the study of international migration. First, the powerful effect of country of education on migration and employment indicates that intertwined institutions shape skilled migrant pathways across the life-course. This highlights the importance of employing institutional perspectives in migration research. Specifically, we can conceptualize life-course transitions in the global education and labor markets (like university enrollment or labor market entry) as migration decisions.

Second, the results emphasize that detailed, dynamic and longitudinal measures of place of education should be centered as a key unit of analysis in the study of skilled migration. This paper builds on previous work showing that foreign degrees largely explain the wage gap for migrants in the United States (Zeng and Xie 2004). This analysis extends the effect of place of education beyond earnings to occupational attainment and migratory behavior and aims to strengthen data measurements. Whereas Zeng and Xie's seminal paper imputes place of education from Census data, the data analyzed in this present study measures place of education directly and captures more granular details about place of education at every degree level and 
field of study, including degrees from multiple countries. With these more detailed and direct measures, the paper's findings show that country of education and degree level matter in understanding labor migration patterns, refining Zeng and Xie's imputed estimates relying on highest degree alone.

\section{Literature Review}

\section{Individual-level factors shaping skilled labor migration}

Labor migration patterns can be studied through labor market participation. Most skilled migrants enter the United States on employer-sponsored work visas that directly link migration to employment (Jasso 2011). Thus, U.S. labor market entry can function as a labor migration pathway (Bauder 2006). Further, U.S. labor market persistence can indicate long-term or permanent immigrant settlement (Chiswick 2011). Studying employment widely captures patterns of migration for skilled labor migrants, but it is an imperfect measure as it misses those who are not currently in the labor market, due to unemployment or a lack of work authorization.

A long-standing sociological literature shows that labor market participation is influenced by many complex and intersecting dynamics related to, among other factors, educational attainment and gender. Higher levels of education are often related to higher rates of employment in higher-status occupations. (Lucas 2001; Torche 2011; Bills, Di Stasio and Gerxhani 2017). Alumni networks and employer on-campus recruitment play an important role in the school-to-work transition and achieving a labor market match ${ }^{1}$ (Granovetter 1995; Lin 2001; Marsden and Gorman 2001; Obukhova and Lan 2013; Lutter 2015; Rivera 2012; Binder et al. 2016). Women have overtaken men in secondary educational attainment and the gender gap

\footnotetext{
${ }^{1}$ Migrant social networks often drive migration decisions and employment patterns, yet migrants who have access to social networks outside of their co-ethnic group see additional benefits; therefore, I expect the effect of these forms of social capital to be even stronger for U.S.-educated migrants (Curran and Rivero-Fuentes 2003; Xie and Gough 2011; Garip and Asad 2016).
} 
in labor force participation has narrowed significantly, yet there remains considerable variation across occupations and industries, especially in STEM fields (Gabriel and Schmitz 2007; Cotter, Hermsen and England 2008; England 2010; DiPrete and Buchmann 2013; Glass et al 2013; Goldin and Mitchell 2017; Blau and Kahn 2017).

For migrants entering a foreign labor market, employment is further shaped by legal status and inefficiencies in human capital transfers. Research on skilled migrant labor market incorporation shows that a foreign education, even from the most prestigious international universities, is less valuable than a U.S. education in determining wages and occupational attainment in the U.S. labor market (Zeng and Xie 2004; Chiswick 2011; Lesky 2011; McDonald et al. 2011). Credential transferring can further block employment: specific fields can require occupational licensing and professional qualifications from the nation where an individual is practicing. Fields like law and medicine in the United States require a certification from an American board; in Canada, engineers, nurses and doctors must hold a qualification from an accredited Canadian institution; Indian citizens with foreign medical degrees were not permitted to practice medicine in India until 2010 (Boyd and Thomas 2002; Wildavsky 2010; Ozden 2006; Walton-Roberts 2020). Further, some migrants, despite being highly educated, are not authorized to work because they arrive on spousal dependent visas (Banerjee 2019).

Given these inefficiencies in human capital transfer, and the close relationship between labor market entry and skilled migration, the research is inconclusive on how human capital influences global mobility. Some scholars argue that education and skills may not be the best indicators of an immigrant's labor market prospects due to human capital devaluation in foreign markets and a potential downward shift in status from origin to receiving context (Bauder 2006). Anticipating a relative degrading of their economic, occupational and social position relative to 
the general population, some might opt to remain in their origin country and maintain their elite status (Stark and Taylor 1989; Chiswick 1999; Engzell and Ichou 2019). At the same time, others have emphasized structural changes in a global economy driving high labor demand for skilled migrants that pulls them to global centers of production (Sassen 1991; Batalova 2006;

Chiswick 2011; Hanson, Kerr and Turner 2018). From this perspective, "human capital can take you where you want to go," as elite workers exercise high levels of global mobility in the global labor market (Ong 1999; Smith and Favell 2006; Massey and Akresh 2006; Cornelius, Espenshade and Salehyan 2011).

On their own, standard individual-level human capital theories are insufficient in explaining skilled migrant pathways between the United States and India. These processes are enabled by corporate institutions like contracting companies, research universities and multinational firms that move skilled migrants through global employment circuits (Banerjee 2006; Sassen 2007; Vijaya and Biswas 2017). The following section develops an institutional perspective that links individual-level migration behavior across the life-course to the academic, corporate and state contexts in which they are embedded.

\section{Linking institutions across the skilled migrant life course}

Life course research emphasizes the linkages and transitions between life events, and how these events fit together to form larger trajectories (Elder 1985). From this perspective, we can see that migration is a self-perpetuating social process that unfolds over the life-course, rather than standard economic approaches that treat it as a singular, linear event driven by wage differentials (Kõu and Bailey 2014). Migration scholars have incorporated the life course perspective to explain key dynamics of migration behavior, from how migration can precipitate or delay marriage, to its varied impacts on employment trajectories across contexts, to how past 
migrations increase the likelihood for future migrations, to how migration itself can function as a key life course event (Massey 1987; Massey and España 1987; Parrado 2004; Flippen and Parrado 2015). Compared to migrants with lower levels of human capital, skilled migrants have more agency in deciding where they want to live and work, which can lead to dynamic, nonlinear migration patterns.

Skilled migrants also offer a powerful case of understanding how individual-level factors and life-course decisions are structured by institutions. Because they are often migrating legally on student or work visas that affiliate them with specific corporate and academic organizations, skilled migrants are embedded in institutional processes and policies across the migration journey. Institutions set the stage for skilled migration; functioning as gatekeepers and constructing pathways, they provide opportunities and constraints for skilled migrants looking to study and work abroad (Sassen 2007; Bailey and Mulder 2017).

Universities, companies and the state play a crucial role in three dimensions of skilled migration. First, institutions develop skills and knowledge through academic study and on-thejob training (Jacobs 2020b; Liu-Farrer, Yeoh and Baas 2020). Second, institutions enable and regulate migration flows, as student and work visas are tied to university enrollment or corporate employment (Rosenzweig 2008; Jasso 2011). Schooling, for example, can provide an important entry point into desired labor markets for talented individuals, or act as a buffer until a labor market match is realized (Munshi and Rosenzweig 2006; Rosenzweig 2008; Grogger and Hanson 2013; Bound, Demirci, Khanna, and Turner 2015; Kerr et al. 2016). Migrants have also been shown to seek student visas with hopes of eventually securing long-term or permanent residence status (Chiswick 1999; Bhagwati and Rao 1999; Clark, Hatton, and Williamson 2007). Third, the institutional context of reception is an essential factor in shaping immigrant 
incorporation outcomes (Perlmann 2005; Alba and Nee 2006; Alba and Foner 2012). The institutions and policies that receive migrants in different educational, economic, and social "modes of incorporation" can influence how migrants fare in educational attainment, wages, employment, and social incorporation (Portes and Zhou 1993; Hudson 2007; Gonzales 2016).

These institutions are all interlinked in a corporate-academic-state "triple helix" that work in tandem and in tension in shaping skilled migration (Etzkowitz and Zhou 2017). Immigration policies fundamentally structure the global higher education and the global labor markets, and these systems are becoming increasingly integrated in "more nuanced and thought-provoking ways" than demonstrated in previous research (Ozden and Phillips 2015, 1). Guest worker programs like the H-1B visa produce labor conditions in which migrants work and regulate the supply of migrant labor in receiving country labor markets (Castells 2002; Bauder 2006). Work visas can affect student enrollment patterns as well: declines in the availability of high-skilled visas made American universities less attractive to foreign students as immigration policies can block or constrain the school-to-work transition for migrants who do not obtain work authorization (Rosenzweig 2008; Kato and Sparber 2013; Amuedo-Dorantes and Furtado 2016). In turn, student visas regulate international students' legal status and student enrollment in the United States and determine the conditions of their study; a termination of student status can result in termination of legal status as well (Jasso 2009). In other instances, stringent employment migration policies might lead migrants to obtain additional educational experience, or tailor their education to fit with visa requirements (Jacobs 2020a).

Locating skilled migration within institutional pathways and across the life course, I conceptualize life-course transitions in the global education and labor markets as migration transitions. As Figure 1 illustrates, college enrollment decisions in the global education market 
are not simply about what school to attend but also what country to study in. Similarly, entering the labor market is not just a decision about what employer to work for, but also what country to work in. Each subsequent pursuit of further education or change in employment can raise similar inflection points in migration decision-making. This can create complex, dynamic migration patterns that unfold across overlapping institutional contexts across the life-course.

\section{Dynamic migration flows, static survey data}

New methodological approaches are needed to study the skilled migration patterns from the linked institutional life-course perspective developed above. The dynamism and complexity of international migration is difficult to capture in cross-sectional, single-country datasets that are constrained by time and space (Levitt and Glick Schiller 2004). Surveys and Census data centered on a specific population living in a specific country at a specific point in time do not capture temporary, circular and return migrants engaging in dynamic in- and out-migration. Further, cross-sectional surveys are not able to provide detailed longitudinal data on migrants' employment histories. While the utility of life history data has been demonstrated for less skilled Mexico-U.S. migration, particularly the Mexican Migration Project (Massey 1987), comparable information on skilled flows and those from other sending regions remains scarce.

In the tradition of cross-border data collection like the MMP, this project utilizes a transnational and longitudinal data design based on in-depth interview data and employment history data developed from public LinkedIn profiles to trace migrants as they move across international borders and move beyond the methodological and conceptual logics of the nationstate (Basch, Glick-Schiller and Szanton-Blanc 1994; Wimmer and Glick-Schiller 2002; Waldinger 2015). The rich information available on employment networking platforms allows for an examination of the linkages between the U.S. and Indian education and labor markets. In 
this paper, I use global labor market participation to examine migration patterns. I trace migrant pathways from Bachelor's graduation to first job and current job, using location information to mark international migration events. Current job is used as a proxy for long-term settlement in the United States, though assessing patterns of settlement raises challenges related to rightcensoring. Migration behavior is an ongoing phenomenon; migrants can be considered "settled" insofar as they have not yet returned to their country of origin. Most studies of migrant settlement focus on settlement intentions, or measure permanent legal status, though some have noted that that does not necessarily indicate permanent settlement (Portes 2003).

This paper examines a multi-level institutional framework that asks how country of education - mediated by intersecting policies and practices at universities, companies and the state - shapes migration pathways in entering and staying in the U.S. labor market. Building on this framework and emphasizing the linkages between life-course transitions in the global education and labor markets, the paper outlines two hypotheses. First, given the strong relationship between human capital, mobility and occupational outcomes, I expect to find that higher levels of educational attainment will lead to higher levels of current employment in the United States. This will indicate higher levels of labor migration and longer-term immigrant settlement. Second, taking corporate and academic institutions as migration gatekeepers that create pathways for study and work, I expect that a university degree awarded in the United States will have a stronger effect on U.S. labor market entry and persistence than comparable Indian credentials.

\section{Data and Methods}

\section{Employment history data}


To develop a macro-level understanding of dynamic skilled migration patterns, I construct a transnational and longitudinal dataset of migration histories using location information embedded in LinkedIn employment history data. LinkedIn is a professional networking website with over 500 million registered users in over 200 countries. It is especially useful to track the movement of skilled labor migrants between India and the United States, the two countries with the most registered LinkedIn users. As the industry standard in many sectors of the U.S. and global economy, it is especially widely used in the technology and business sectors and among workers early in their career, further capturing key dimensions of U.S.-Indian skilled migration (Statista 2018; Waldman 2016). Because users rely on LinkedIn for job recruitment, this platform offers detailed and current information about workers' employment and location history. Thus, LinkedIn presents a novel resource to study a highly mobile population that is often missing from Census and survey datasets. It is increasingly being used as a data source for social scientific research on job search behavior, employer recruitment, innovation and patenting but this will be one of the first studies to bring this data source to the research on international migration (Wadhwa et al. 2011; Ge et al. 2014; State et al. 2014; Horton and Tambe 2015; Breschi et al. 2019).

Drawing on Tambe and Hitt's (2014) work analyzing employment histories constructed through LinkedIn data, I construct migration histories through location data reported in LinkedIn profiles. These data give purchase on many important phenomena on both educational and employment history that are difficult to study in other datasets due to lack of detail (Docquier and Rappoport 2012). Each employment entry includes locational information at the city and country level as well as duration of employment, which offers a novel way to measure where and how long migrants worked. In addition to documenting migrants' full reported employment 
histories, I also recorded each migrants' educational history, including all Baccalaureate and postsecondary degrees and coded the information by the country where the degree was earned. Finally, I captured field of study through reported majors. In this analysis, I take advantage of the location information in education and employment details to analyze variation in settlement patterns by place of education.

\section{Sample characteristics}

Scraping data from LinkedIn profiles, I constructed a sample of 7,177 Indian skilled evermigrants to the United States. Skilled ever-migrants are defined as anyone who studied or worked in the United States for more than six months, and hold at least a Bachelor's degree (the minimum educational requirement for U.S. skilled work visas). Migrants in the sample hold Bachelor's degrees from Indian and U.S. universities.

Table 1 presents the descriptive statistics for the independent variables used in the analysis. The employment history sample includes 2,556 U.S. Bachelor's degree holders and 4,621 Indian Bachelor's degree holders. The migrant Indian Bachelor's population includes migrants who moved to the United States for either work or study - some obtained an advanced degree at a U.S. institution, while others moved for a job. More than three-quarters of the sample has an advanced degree, and 64 percent of Indian Bachelor's graduates went on to obtain a U.S. Master's, highlighting the multinational nature of skilled migrant educational attainment. Ninetythree percent of migrants in the sample has at least six months of U.S. work experience.

\section{Measures}

Country of employment. This outcome variable measures country of employment in the United States (1) versus India (0) at first job (Table 3) and current job (Table 4). Each location was coded through the information reported with each job entry at the city, state and country 
level. Country of employment is used as a proxy for a migrant's location at each employment entry. $^{2} 3$

Educational attainment and location. I operationalize educational attainment as the degree level (Bachelor's, Master's, or Doctorate) and country in which that degree was obtained (United States, India or Other). I constructed four mutually exclusive dummy variables distinguishing between migrants with Bachelor's or advanced degrees from India or the United States: U.S. Bachelor's only; Indian Bachelor's, U.S. advanced; U.S. Bachelor's, U.S. advanced; and any Bachelor's, Indian advanced. ${ }^{4}$ Country of degree was coded based on the location of each school listed in a user profile. Educational attainment at first job reports only the degrees held in the year a worker first entered the labor market.

Employment history. I include a variable "ever-worked in India" in the supplemental analysis of the current job models (Table C1). This variable measures any previous employment in India before a migrant's current job.

Gender. I construct a dichotomous variable "male" through coding migrants" genders as presented in their profile name and picture (LinkedIn profiles do not self-report gender). While

\footnotetext{
${ }^{2}$ This measure is conditional on being in the labor force -- the LinkedIn sampling frame largely captures people who are currently employed or actively seeking employment. There may be non-random selection of people excluded from this sampling strategy. While some people might update their profile to indicate current unemployment, this sample cannot systematically measure the unemployed skilled migrant population, assuming unemployed migrants not actively seeking employment might not have LinkedIn profiles. Further, gender can affect the employment patterns of skilled migrants. Specifically, skilled migrant women on H-4 spousal visas who are not authorized to work in the United States may not be fully captured in this sampling approach. This might bias the sample towards more female employment in the United States than is reflected in the full migrant population, but might also underestimate the full population of skilled migrant women settling in the United States.

${ }^{3}$ As discussed in the literature review, this paper conceptualizes the overlaps between U.S. labor market participation and U.S. labor migration, which allows me to use the location data in employment histories to measure migration behavior. In this study, U.S. employment is intended to measure migration behavior; it is not intended to speak to individual-level indicators of immigrant quality, or institutional-level status hierarchies between U.S. and Indian labor markets.

${ }^{4}$ To generate more statistical power, all Indian advanced degree holders are analyzed together regardless of whether they received a Bachelor's degree in the United States or India. The sample has a low frequency of U.S. Bachelor's degree holders obtaining Indian advanced degree, which substantively suggests a uni-directional flow of multinational educational migration from India to the United States, rather than vice-versa (Jacobs 2020a).
} 
this conflates notions of gender identity and gender presentation, the focus of the analysis in this paper is how social interactions and treatment by the state are shaped by gender, which widely depends on external presentation and the version of presented in professional settings, like LinkedIn profile pages.

Other controls. I include several additional controls, including whether their highest degree was earned in a STEM field (1) or a non-STEM field (0), to examine the influence of field of study on employment outcomes. I also examine graduation cohort and time of labor market entry relative to the 2008 financial crisis. When predicting the likelihood of a first job in the United States, I factor in the year a migrant first entered the labor market, which adjusts for people who worked before returning to school for an advanced degree. When I turn the analysis to current job in the United States, I focus on graduation cohort of highest degree to examine the dynamics of a migrant's current labor market spell.

\section{Empirical strategy}

To examine the relationship between country of education and employment location, I estimated binary logistic regression models using Stata. I predict the likelihood of first job and current job in the United States in two separate analyses. I use employment location as an indicator of labor migration. While there is an issue of right-censoring among migrants currently working in the United States (haven't yet returned to India), I interpret current job in the United States as a form of longer-term or permanent settlement, while the analysis of first job in the United States focuses on more temporary migration.

I supplement this analysis with parallel model specifications using OLS linear probability models, which allow for an estimation of differences by gender with interaction terms. I use linear probability models rather than logit models to examine interaction effects to address issues 
with the interpretation of coefficients of the interaction terms in nonlinear models with categorical dependent variables (Mood 2010; Mustillo, Lizardo and McVeigh 2018).

The primary model reported in Table 3 (Model 2) regresses first job country as a function of educational attainment, field of study, year of labor market entry, and gender. This model should help to estimate the likelihood of first job in the United States. Supplementary analysis in Tables A1 and A2 stratify the sample by country of Baccalaureate to focus on the effect of country of education among advanced degree holders. Table B includes supplementary linear probability OLS regression analysis that incorporates gender interaction terms and the same controls (Model 3). This interacted model should help to determine whether the effect of a U.S. education is moderated by gender. The analysis reported in Tables 4, C1, C2 and D, predicting current job in the United States, employs a similar empirical strategy and includes similar variables in the model specification.

Table C1 incorporates employment history among Indian Bachelor's holders to examine the effect of prior Indian labor market experience. Employment history was excluded from the analysis for first job in Table 3, because migrants did not have prior employment experience at time of first job. Because of small sample sizes of U.S. Bachelor's degree holders with Indian labor market experience, this variable was not included in the main analysis in Table 4 or the stratified analysis in Table C2. The infrequency of U.S. Bachelor's degree holders returning to work in the Indian labor market (1.8 percent of the full sample) substantively indicates the rarity of this pathway, even without estimating this effect in regression models.

\section{Interview data and empirical approach}

To understand the institutional processes and mechanisms driving the patterns of skilled migration established in the employment history data, this paper draws on 105 in-depth 
interviews with Indian-citizen graduates of Indian and U.S. universities, as well as current students, university administrators, hiring managers and immigration lawyers. These data address the paper's research question about how U.S. and Indian degrees translate into the U.S. labor market by providing insights into the school-to-work transition and hiring process. Interviews with skilled migrants offer a window into how individuals navigate this transition, while university administrators, hiring managers and immigration lawyers show how institutions approach U.S. and foreign educations differently.

I use the descriptive statistics from the LinkedIn employment history data to establish the sampling frame and recruitment strategy for in-depth interviews with skilled migrants. The key characteristics of the interview sample largely reflect the LinkedIn dataset in terms of age, degree type, major, industry, and other relevant characteristics; however, I oversample on underrepresented groups of interest such as women and return migrants. Interviewees were recruited directly from the LinkedIn population and snowball sampling was used to identify additional interviewees. The direct link between the two data sources offers an opportunity for additional validity checks and helps to illuminate some of the unobserved issues related to unemployment.

I conducted interviews between June 2019 and March 2020 in India (New Delhi, Gurgaon and Bangalore) and the United States (Philadelphia, New York, New Jersey and the San Francisco Bay Area). I held interviews in person and on the phone via WhatsApp, and all conversations were in English. Interviews lasted between twenty-eight minutes and two hours, with an average length of forty-eight minutes. All interviews were transcribed and analyzed using NVivo, a qualitative data analysis computer software package, and identifying information 
like the interviewee's name, university and company have been modified to protect respondent identities.

\section{Results}

Table 2 examines country of first and current job by place of education and shows that there is a strong relationship between the country in which a migrant obtained their degree and their entrance and persistence in national labor markets. As shown in Table 2, U.S. graduates held a first job and current job in the United States at higher rates than graduates of Indian universities. U.S. graduates enter the U.S. labor market; Indian graduates enter the Indian labor market. Eighty-six percent of U.S. Bachelor's degree holders first worked in the United States compared to only 24 percent among Indian degree holders, 68 percent of whom first worked in India. Six percent of U.S. Bachelor's degree holders and eight percent of Indian graduates worked in a third country at first job.

This strong relationship between country of employment and country of education persists when examining current job location. Table 2 shows that U.S.-educated migrants in this sample are currently working in the United States at higher rates than those with foreign educations. This pattern persists across levels of educational attainment: migrants with a U.S. Bachelor's, Master's or Doctorate currently hold a job in the United States at higher rates than those with Indian degrees at equivalent levels. It also persists among U.S.-educated migrants who earned their most recent degree at least five years ago, and have been in the labor market for that duration.

When looking at the patterns of first job and current job together, Table 2 indicates that U.S.-educated migrants enter the U.S. labor market directly after graduation while Indianeducated migrants first work in India and then some enter the U.S. labor market after a period of 
time in the Indian labor market. Twenty-four percent of Indian Bachelor's degree holders held a first job in the United States, while 61 percent currently hold a job in the United States. Eightysix percent of U.S. college graduates entered the U.S. labor market at first job, and 83 percent remained at current job.

\section{Predicting first job in the United States}

To explain the factors and pathways leading to entering the U.S. labor market after graduation, I estimated binary logistic regressions predicting first job in the United States. The predictors center on educational characteristics, including place of education, degree level, field of study, and graduation cohort, as well as gender and employment history. Results, presented in Table 3, show a clear effect of U.S. education on entering the U.S. labor market directly after graduation. $^{5}$

At both the Bachelor's and advanced degree levels, having a U.S. education is a strong positive predictor of holding a first job in the United States. As shown in Model 1, the odds of a first job in the United States for U.S. Bachelor's degree holders are 20.4 times the corresponding odds for Indian Bachelor's degree holders (coefficient=3.017). At the U.S. advanced degree level, the odds for migrants with a U.S. Bachelor's and U.S. advanced degree increase to 22.9 times the odds for those with only an Indian Bachelor's (coefficient=3.135). And a U.S. advanced degree has a strong positive effect for those who completed their undergraduate studies in India: the odds of a first job in the United States for migrants with an Indian Bachelor's degree and a U.S. advanced degree are 12.3 times the corresponding odds for those with only an Indian Bachelor's (coefficient=2.506).

\footnotetext{
${ }^{5}$ This outcome measures first job after obtaining a Bachelor's degree. Some people entered the labor market and worked for a period of time before returning to school; this outcome only considers their level of educational attainment at the time of first job. Similarly, for those who obtained advanced degrees directly after their Bachelor's studies before holding a first job, all of their educational attainment at time of first job is analyzed.
} 
The positive effect of a U.S. education on the likelihood of a first job in the United States at all degree levels persists when field of study, year of first job and gender are incorporated in Model 2. This effect also persists in Tables A1 and A2, which stratifies the sample by country of Baccalaureate to hone in on the effect of country of education at advanced degree. Both tables show that advanced U.S. degrees are a positive predictor of a first job in the United States, especially for those with Indian Bachelor's degrees.

The results in Table 3 show a marginal positive effect (coefficient $=0.228$ ) of holding an Indian advanced degree on first job in the U.S. relative to those with an Indian Bachelor's degree only, though this effect is statistically significant only at the $p<.1$ threshold in both models and has no statistical significance in supplementary linear probability models presented in Table B. In the stratified analyses in Tables A1 and A2, Advanced Indian degrees do not have a statistically significant effect on first job in the U.S. for Indian Bachelor's graduates, and have a negative effect on U.S. employment for U.S. Bachelor's holders.

The results in Model 2 in Table 3 show that holding a STEM degree and graduating after the 2008 financial crisis have positive effects on first job in the United States. Model 2 also shows that gender does not have a statistically significant effect on U.S. employment at first job. To unpack these dynamics further and determine if the effect of place of education is moderated by gender, I run a supplementary analysis of linear probability OLS regressions that incorporate an interacted model. Table A reports the results of this analysis and shows that the lack of a gender effect persists.

\section{Predicting current job in the United States}

Table 4 reports results from a set of binary logistic regression models employing a similar empirical strategy that predicts location of current employment. Overall, the models in Table 4 
illustrate that a U.S. education has a positive effect of currently working in the United States, and country of degree matters more than level of educational attainment for settlement patterns.

These effects are smaller than first job but their persistence across migrant's careers suggests the legacy effect of country of education across the life-course.

The positive effect of a U.S. education on the likelihood of currently working in the United States at all degree levels persists across both models in Table 4. The odds of migrants with a U.S. Bachelor's degree currently working in the U.S. are 3.03 times the corresponding odds for Indian Bachelor's degree holders (coefficient=1.110); for U.S. advanced degree holders with a U.S. Baccalaureate, the odds increase to 5.6 times the corresponding odds for Indian Bachelor's degree holders (coefficient=1.721). U.S. advanced degree holders with an Indian Baccalaureate are also more likely to be working in the United States, relative to those with just an Indian undergraduate education (odds ratio=3.01; coefficient=1.102).

Interestingly, Indian advanced degree holders are less likely to be currently holding a job in the United States than those whose highest degree is an Indian Bachelor's. The odds for Indian advanced degree holders is 0.66 times the corresponding odds for those with just an Indian Bachelor's (coefficient $=-0.415$ ). In other words, the odds of current U.S. employment are about 34 percent smaller for more highly educated Indian-educated migrants. Holding an Indian Master's or Doctorate degree has a persistent and statistically significant negative effect of currently working in the United States in Model 2, which controls for graduation cohort, years in the labor market and gender. These dynamics also persist in Tables $\mathrm{C} 1$ and $\mathrm{C} 2$, which stratify the sample by country of Baccalaureate and show that advanced U.S. degrees are a positive predictor of U.S. labor market participation, while advanced Indian degrees are a negative predictor. 
Table 4, Model 2 shows that holding a STEM degree and graduating more than two years after the 2008 financial crisis are positive predictors of current U.S. employment. This model also incorporates an analysis of gender to examine variation in current U.S. employment by men and women. It shows that men are somewhat more likely to return to Indian than their female counterparts. The supplementary analysis linear probability OLS regression models in Table D runs interactions between education history, field of study and graduation cohort. When examining the interaction between gender and educational history, the positive effect of a U.S. degree on currently working in the United States is stronger for women than for men across degree levels, meaning that women with a U.S. Bachelor's or advanced degree are more likely to be currently working in the United States, relative to men with the same educational attainment.

Recall that gender does not have a statistically significant effect on the likelihood of first working in the United States in Table 3; the positive and significant effect for current job suggests that the gender differential grows over time as migrants spend more time in the labor market. The results of these two tables indicates that the relationship between gender and education, and gender and labor market experience are not linear and become more pronounced over time. In the first job models, the effect of gender is widely explained by the positive effect of a U.S. Bachelor's degree on first job in the United States. In the current job models, the interaction between gender and labor market experience becomes clearer, with men being more likely to return to India than women, significant at the $p \leq .001$ level. This indicates that labor market experience and gender dynamics in the labor market are playing a considerable role in shaping migrant settlement pathways for men and women. This is consistent with previous research that shows that men are more likely to be temporary migrants than women while women are more likely to settle permanently, and that the U.S. labor market is relatively 
friendlier to women than the Indian labor market (Hondagneu-Sotelo 1994; Kofman 2004; Gupta 2012; Varma and Kapur 2015).

To examine the effect of employment history on currently working in the United States, Table $\mathrm{C} 1$ adds Indian labor market experience to the model specification. This table shows that among those with an Indian education, migrants who ever-worked in India are less likely to be currently working in the U.S., relative to those with no Indian labor market experience. This effect might indicate a negative legacy effect of foreign labor market experience on U.S. employment, as companies might not value foreign employment at the same level as U.S. employment, or might illustrate a contract work pathway, where migrants working for Indianbased companies temporarily transfer to a project in the United States. Conversely, it might indicate positive selection dynamics among those who returned to India and experienced career success, upward mobility and deepening professional network ties that opened up new employment opportunities in the Indian labor market.

Taken together, the results reported in Tables 3 and 4, as well as the supplementary analyses, show that country of education shapes migrant pathways both in entering the U.S. labor market and staying in the U.S. labor market. A U.S. education is a strong and persistent positive predictor of both first job in U.S. and current U.S. employment at the Bachelor and advanced degree levels. The effect is very strong for first job and persists and remains positive even as migrants spend more years in the labor market.

The effect of an Indian education on first job and current job in the United States is more complex. In predicting first job, an Indian advanced degree does not offer much explanatory power in determining why a migrant first works in the United States. The effect is marginally positive in Table 3. In Table A2, Indian advanced degrees have a negative effect of U.S. 
employment at first job relative to those with just a U.S. Bachelor's degree. Tables 4, C1 and C2 indicate that as migrants' labor market experience continues, higher levels of human capital do not keep migrants in the U.S. labor market. Indian advanced degree holders are less likely to be currently working in the United States than those with only an Indian or a U.S. Bachelor's degree. Thus, higher levels of educational attainment do not lead to U.S. labor market entry or permanent U.S. settlement, contradicting standard theories of human capital and migration.

\section{Qualitative insights on pathways to entering the U.S. labor market}

While the LinkedIn data suggest a clear relationship between country of education and U.S. labor market entrance and persistence, a more qualitative, in-depth approach is needed to understand what dynamics are shaping these patterns. The interview data shows that immigration policies in universities and workplaces create migration opportunities, but also come with limitations and constraints that influence how migrants navigate these institutions across the life course. These findings illustrate how education and employment context influences decisions about settlement or return.

Results highlight how institutions create multiple pathways to entering the U.S. labor market. Interviews with university administrators showed how universities support migrants on student visas in the school-to-work transition by providing resources on work authorization in the United States. HR managers described how employers directly recruit skilled migrants into certain industries and how Indian-based companies contract migrants on specific projects that directly match workers with an employer in the United States.

The interview data indicates that a U.S. education creates a strong pathway to entering the U.S. labor market. Administrators detailed the ways that universities and companies collaborated in creating pathways for U.S. international students through organizing career fairs and providing 
resources for obtaining U.S. work authorization. Further, recruiters and hiring managers indicated U.S. employers displayed a preference for U.S. credentials. The strong relationship between a U.S. education and U.S. labor market experience also in part reflects self-selection among migrants. Interviews with skilled migrants indicated that some saw enrollment in a U.S. university as a pathway to the U.S. labor market, while others stayed in the U.S. for work to earn higher salaries with the goal of paying off student loans that funded their U.S. educations.

For many migrants, entering the U.S. labor market started with the decision to study in the United States, echoing life-course perspectives that emphasize how life events fit together to form larger trajectories. U.S.-educated migrants described U.S. universities as a gateway to working in the United States and said they tailored their educational attainment for future labor market opportunities. "Living in the U.S. was always endgame for me, and coming for school was the best way to accomplish that. You get your foot in the door as a student, and then you can just stay," said Manohar, who studied on the West Coast and now works in California.

Universities help international students transition from the U.S. education system into the U.S. labor market by providing institutional support. Administrators in career services and international student offices described collaborations through career fairs and advising sessions for international students about how to obtain U.S. work authorization. They said international student offices often organize events about U.S. work options for international students after graduation, which emphasize the different pathways for students to stay in the country.

At one information session at an elite university on the East Coast, an immigration lawyer invited by the international student office explained the work authorization process to a room of international students. "I'm here to help you understand the immigration process so that you can stay in the United States," he said. "I'm not going to sugar coat it for you: it won't be easy. But I 
think you'll find that in the end, it's worth the effort for the opportunities you can find here." These information sessions are bolstered by an international student office that provides advising for students on how to transition their student visa to a work visa and support in keeping documents current and accurate.

In addition to sharing information about navigating U.S. immigration policy, U.S. universities and companies collaborated in employee recruitment, emphasizing work authorization as a central component of the process. "We work very closely with companies to place our students in good careers, and part of that is making sure they can get a visa if they need one. Students come to school here to get good jobs working in the States, so it's a lot of pressure on our office to deliver," said a career services officer at an Ivy League school. "[Our company partnerships] are a win-win... we work with places that I know make good employers...with good work environments, who sponsor visas... and on their end, they know we have students who make great employees."

Hiring managers described employer hiring practices that also advantaged U.S.-educated job applicants over foreign applicants. In some cases, employers struggled to recognize or assess foreign educations because they were unfamiliar with the university system abroad. One hiring manager in Silicon Valley admitted some confusion when assessing the credentials of foreigneducated applicants. “There have been times where I can't really make heads or tails of someone's education, if it's from another country. I don't recognize the school, or they weren't in school for that many years, or the degree is different. Like, is this a Master's degree or something else?" she asked.

This HR manager's confusion reflects differences in the U.S. and Indian education systems, where an Indian Bachelor's degree is often granted in three years, and some universities 
offer degrees unavailable in the United States, like a Bachelor's in Technology (B.Tech). This issue was less common in industries like technology where companies hire more foreigneducated workers, and human resources staff are more familiar with international university systems; however, this indicates some constraints in the labor market pathways available to foreign-educated migrants. Further, immigration lawyers said that USCIS visa processing officials often cited inconsistencies in migrants' educational attainment (questioning degree equivalency or years of education) as a reason for a Request for Evidence in H-1B applications, which slowed down the visa processing time and in some cases resulted in a rejected application, further highlighting how foreign educations constrained entrance into the U.S. labor market.

Even in industries where foreign credentials were recognizable and legible to employers, many employers in this study indicated that they gave preference to U.S. credentials when making hiring decisions. Whereas potential employers were sometimes unfamiliar with the prestige of top-ranked foreign schools, they frequently lauded the status of U.S. institutions. "If I'm weeding out resumes and picking applicants for a job, the ones that jump out at me are the top U.S. schools, the Harvards, the Stanfords... you know, the names we all know," said one hiring manager at a startup in Chicago. When asked about the prestige of top-ranked universities in India, he said he understood that they were good schools, but did not feel the same preference for graduates. “There's kind of a knee-jerk reaction when you see an Ivy at the top of someone's resume, you know? You can't help but be a little more interested. I've had tons of applications from foreign schools, and we've definitely had some success from a few of the Indian schools, but I guess I just don't know them as well.”

The power of institutional prestige did not fully translate from foreign universities. After describing his high esteem for elite U.S. Ivy League schools, the Chicago-based hiring manager 
said that he was less impressed with top-ranked Indian universities. "I've had applicants come in with this chip on their shoulder, telling me how great they are because they went to so-and-so school... the name just doesn't have the same wow-factor for me. I'm sure they're smart... but it's pretty off-putting... makes you wonder, 'do I want to work with someone who thinks so highly of themself?"”

Some of this preference for elite U.S. schools resulted from heavily recruiting through alumni networks. Employers who used these strategies said they encouraged their workers to advertise for jobs within their personal and professional networks, and sometimes offered incentives for referring job candidates. Emphasizing "cultural fit" and personal connections, a product designer at an e-commerce company in California said, "our two founders got their start while getting their MBAs together, and we always make a point to try to recruit within that network as much as possible... we've hired a lot of friends of friends, former classmates, that kind of thing. It makes it easier... especially if they're from outside the U.S... because we know what kinds of training they've got from school, and we know they'll fit with the culture. That's where we came from too." He emphasized that this U.S. institutional context was especially important for foreign-born job applicants because it indicated a level of immigrant assimilation. "It gives more context if they're coming from somewhere else... it means they're like us."

In some cases, alumni networks proved to be powerful channels to employment that weighed more strongly than an applicant's qualifications. "You need a particular kind of expertise to do this kind of work, so most of the people we hire have some sort of advanced degree. But if we get an applicant that looks really promising who just has a Bachelor's, I'll definitely think about it...we've hired a few who worked out really well," said a recruiter at a tech company in Boston. When asked about the educational background of the employees 
holding a Bachelor's degree, he emphasized U.S.-based social networks and U.S. credentials as indicators of their quality, despite their lower qualifications. He said that he felt "comfortable giving them a chance because most were referred by someone within the company... you know, they went to school together or something... or we hire a lot of people from the same few schools right in the Boston area, there's a good pipeline there... it's good schools and they're already local."

The familiarity and comfort that recruiters described when assessing U.S.-educated applicants, especially from within their own networks, was largely absent when they discussed applicants educated abroad. "We get some applications from people who didn't get their degrees in the U.S., and I know they got a perfectly good education somewhere else, but I'm not convinced they are familiar enough with the U.S., and how things work here," said a tech recruiter in Philadelphia. "In interviews I usually have to pause and think about it, and it makes it harder in the interview process, there's less to talk about because I don't know how the schools work over there."

While employer preference for U.S.-educated migrants creates a specific pathway for those graduating from U.S. universities and transitioning to the U.S. labor market, Indian degree holders followed other pathways that created entrée into employment in the United States. Some Indian-educated U.S. employees were recruited through U.S. companies at career fairs, while others moved to the United States through transnational companies. A third group, recognizing the value of a U.S. education for working in the United States, pursued a U.S. Master's degree after first working in India, and then secured a job in the United States after graduation.

While the ties between U.S. universities and U.S. companies were much stronger, U.S. companies sometimes recruited at Indian universities as well, especially in certain industries 
such as information technology, computer science and management consulting. One Californiabased human resources manager noted that the Indian universities were part of his technology company's broader recruiting strategy. "We usually send someone over to work the recruiting circuit at the Indian tech institutes and find a few people there every year," he said. A career services officer at one of the Indian Institutes of Technology described elaborate recruiting practices from U.S. management consulting firms. "International companies... because they have to travel farther to get here, not all come every year, but the Big Four firms all rush to get here on the first day of recruiting. The first day is for the best companies... ...they lavish people with five-star dinners at the fancy hotels."

Interviews with HR managers at transnational companies show that they create a distinct pathway into the U.S. labor market, highlighting the important role of corporations as institutional actors shaping skilled migrant life-course trajectories. Multinational companies make intra-company transfers on an L visa (lasting between three and seven years) that move an employee to a company office in a different country. Contracting companies, in turn, make intercompany transfers, matching employees of the contracting company with a U.S. company to work on a specific project; the contracting company sponsors and manages the contract worker's H-1B visa, which can last up to six years (See Figure 1 for a typology of all migrant pathways). One analyst at a multinational bank described the process of "bringing people over from the abroad offices" as "pretty fluid," while some immigration lawyers noted that if a migrant worker faced challenges with other work authorization visas while employed at a multinational corporation, they sometimes temporarily transferred them to the office in another country because "L transfers are less complicated." 
"I've been working for the same company for seven years now, first back in Bangalore and now in Seattle," said Sujit, a software engineer with an Indian Bachelor's degree who works in Seattle. "I was working on a project designing the messaging framework for business-tobusiness communication, and then they told me they were starting a similar project in the Seattle office and asked if I could move, to help redesign the monitoring and alert system for advertising between our company and sponsors."

Employees of multinational corporations often said they did not have specific plans to work in the United States before the employment opportunity presented itself. Ritwiz, who works for a technology company with offices in Bangalore and the West Coast of the United States, said that he had no intention of moving to the United States before his boss approached him with the opportunity. "I was hesitant when they asked me...I had no thoughts or goals of coming to the U.S. or relocating away from my family, my friends, nothing of that sort. I told my boss I wasn't sure, but he encouraged me, said I was the right person for the project. So on a whim, I said okay, sure, I'll give it a shot."

Contracting companies match workers a specific employer in the United States on a project-by-project basis, and the worker remains an employee of the contracting company. One talent manager at a contracting company in Bangalore described this process, saying, "A company will write us a spec for what they need, how many people and they'll say the timeframe and write up the requirements of the work... and then we'll go find the guys to do it and bring them over. They're the ones on the ground actually doing the coding and building the [website] architecture."

Some contract workers pursue these kinds of projects specifically for the opportunities to work in the United States, despite voicing little workplace satisfaction. "The work environment 
isn't always great. You don't really feel that involved or part of the team... there have been times where I approached them with a specific idea and it was dismissed," said Nitesh, who has worked on a contracted project at a telecommunications company in New Jersey for the last two years. "But working for [company] gave me a chance to go to the States and I am lucky for this opportunity."

\section{Pathways to staying in the U.S. labor market}

After realizing a labor market match with a U.S. employer, migrants are faced with a complex immigration system that determines whether and how long they will be able to work legally in the United States. The terms of their visa, in turn, can also influence the quality of their employment and occupational satisfaction in the United States.

Visa availability plays an important role in how long migrants can work in the United States. Short-term employment is possible on a B-visa (six months) or Optional Practical Training (OPT) through a student visa, that authorizes them to work for one year in a field related to their university degree (USCIS). The H-1B visa, a six-year temporary work visa, has an annual lottery for private employers and only selects about a third of qualified applicants each year, meaning that each year, many qualified migrants with employer sponsorship leave the United States because their visa was not selected. For migrants applying for legal permanent residence status through employer-based Green Cards, wait times can be up to 15 years for Indian citizens, because of annual quotas based on nationality.

These employer-sponsored visas link migrants' employment and legal status, underscoring how government immigration policies and private employers together regulate migrants' legal statuses. Migrants frequently mentioned these overlapping statuses in interviews. As Rupal, a management consultant in New York, said, "If you're fired, you're out," referring to leaving both 
the company and the country. Respondents in this study emphasized that they felt their entwined legal and employment status gave their bosses considerable control and limited their career opportunities in the United States (see Jacobs 2020 b for more).

While migrants described ways that employers leveraged control over their legal status, employers often emphasized how migration policy constrained their ability to hire and retain foreign-born workers, highlighting some of the ways institutions at times work at cross-purposes. "If [an employee] doesn't get the visa in the lottery, there isn't really that much we can do," said the product designer in California. 'I’ve lost some really good people who just didn't get selected, it can be pretty frustrating."

Immigration lawyers said in cases where migrants were not selected in the visa lottery, they advised them to consider other channels to stay in the United States, such as enrolling in a graduate program to obtain a student visa or pursuing a family-sponsored green card. After earning her Bachelor's degree in the United States and finding a job and employer sponsorship, Jyoti's H-1B application was not selected in the annual lottery. She decided to enroll in an MBA program in the United States so that she could obtain a student visa and work through her OPT, with the hopes that she would win the H-1B lottery the following year. "I liked my job, and my boss understood the situation, so we figured out an arrangement where they would send me for an MBA with the understanding that I would come back after, and it would be good for them because I'd have value-add," she said. The immigration lawyers at her company were in the process of preparing her second H-1B application at the time of our interview. This scenario, where a company funded a migrants' advanced education as part of a strategy to develop skills and navigate the migration system, further underlines the linkages between these institutions. 
Despite the challenges migrants faced with overlapping employment and legal statuses, women were more likely to report plans to stay in the U.S. labor market while men were more open to returning to India for work. Women described frustrations with male-dominated workplaces in the United States, but said that they felt their career opportunities were better in the United States than in India. "To be honest, I don't love being the only woman on my team," said Kari, who has worked at a startup company in New York since earning her Bachelor's degree from a U.S. university. “The environment is kind of masculine and I don't feel always respected. But when I think about my alternatives back home... it would be a lot worse."

Women often constructed a reference point to the Indian labor market based on the experiences of friends or relatives, rather than first-hand work at Indian companies. Arya, for example, said, "I have friends back home, they've told me horror stories about their companies. Terrible hours for work, creepy coworkers, horrible bosses, stubborn men... you know how it goes. I'd thought about going home when things weren't looking good here... but the more I thought about it... I realized things were better here than what I'd be able to do back there."

Men, in contrast, were more open to the possibility of remaining in the United States or returning to India. "Things will be fine either way... I'd like to stay [in the U.S.] if I can, I've worked hard to be here... but it has not been settled yet with my green card," said Ritwiz. "I know there would be good opportunities at home... it would be nice to be near my family."

\section{Discussion}

This paper demonstrates the strong effect of country of education on patterns of skilled labor migration in both entering and staying in the U.S. labor market. The results show that where a migrant earned their degree matters more than how many degrees they hold in 
determining U.S. labor market persistence and skilled migrant settlement. This supports the notion of educational institutions as skilled migrant pathways and forwards a multi-level institutional framework that situates individual migration behavior and life-course transitions within the context of intersecting corporate, academic and immigration policies and practices.

The paper combines in-depth interviews with new data sources that capture the dynamism and complexity of international migration in transnational and longitudinal perspective. At the individual level, I find that migrants make decisions about educational attainment and employment that precipitate and facilitate migratory behavior. At the institutional level, universities, companies and the state together function as institutional migrant pathways linked across the life course that enable and constrain migration in and out of the United States.

Binary logistic regression analysis of employment histories indicates that a U.S. education is a strong and persistent positive predictor of both first and current job in the United States, while an Indian education has a negative effect on U.S. employment at all degree levels. The effect is even stronger at advanced degree levels: Indian Master's and Doctorate degree holders are less likely to be currently working in the United States than those with an Indian Bachelor's degree, indicating that higher levels of educational attainment among Indian advanced degree holders does not lead to permanent U.S. settlement. This challenges standard theories of migration and human capital that emphasize high levels of education as an engine for global mobility and settlement, and indicates that migrants might move to the labor market that maximizes their relative status and the value of their educational credentials (Sassen 1991; Portes 2003; Bauder 2006; Smith and Favell 2006; Chiswick 2011; Cornelius, Espenshade and Salehyan 2011). 
In-depth interviews with skilled migrants and institutional actors at universities and companies provide context to these patterns, demonstrating how corporate, academic and government institutions collaborate and work at cross-purposes in creating pathways to entering and staying in the United States. U.S. universities facilitate the school-to-work transition for international students through offering guidance on obtaining U.S. work authorization and coordinating recruitment efforts with companies that sponsor skilled migrants for work visas. Through social networks and credential evaluation, U.S. companies display a preference for U.S. degrees over foreign educations in hiring decisions. The availability of student and work visas can influence whether migrants can legally enter and stay in the country; in some cases, migrants rely on U.S. university enrollment and student visas as a stop-gap measure until they obtain work authorization, sometimes aided and funded by U.S. companies. At the same time, multinational corporations and Indian-based subcontracting companies create distinct pathways for entry into the U.S. labor market through temporary contract work or intra-company transfers.

The findings of this paper have methodological and theoretical implications for future demographic and sociological migration research. The paper underscores the importance of place of education as central unit of analysis in the study of skilled migration. It builds on previous research establishing the effect of foreign degrees on migrant wage differentials to show that foreign educations influence migration patterns in addition to occupational outcomes. The data presented here offer a detailed and direct measure of place of education; where previous studies relied on imputed data and estimates focused on country of highest degree, the employment histories in this study directly measure country of education and show that complex, multinational educational attainment at different degree levels influences migration behavior in important ways (Zeng and Xie 2004). Thus, it shows why researchers should incorporate detailed 
measures of place of education into their analysis and presents new data sources for furthering this empirical approach in future research.

As the paper indicates, skilled migrant settlement depends more on where a migrant earned their degree than how many degrees they earned. This finding has important implications for understanding fissures in the integration of the global education system into the global labor market, and will interest companies trying to recruit top global talent. On a more conceptual level, this suggests that migration scholars should look beyond individual-level characteristics to the institutional context shaping skilled migration flows and incorporation, building on the multilevel institutional life-course framework forwarded in this paper. I offer a new conceptualization of life-course transitions in the global education and labor market as migration decisions. 
Alba, Richard and Victor Nee. 2003. Remaking the American Mainstream: Assimilation and Contemporary Immigration. Cambridge, MA: Harvard University Press.

Alba, Richard and Nancy Foner. 2015. Strangers No More: Immigration and the Challenges of Integration in North America and Western Europe. Princeton: Princeton University Press.

Amuedo-Dorantes, Catalina and Delia Furtado. 2016. "Settling for Academia? H-1b Visas and the Career Choices of International Students in the United States." (IZA Discussion Paper No. 10166). Bonn: IZA.

Bailey, Ajay and Clara Mulder. 2017. "Highly Skilled Migration between the Global North and South: Gender, Life Courses and Institutions." Journal of Ethnic and Migration Studies 43(16):2689-2703.

Basch, Linda, Nina Glick-Schiller and Cristina Szanton-Blanc. 1994. Nations Unbound. New York: Routledge.

Banerjee, Pallavi. 2019. "Subversive Self-Employment: Intersectionality and Self-Employment Among Dependent Visas Holders in the United States.” American Behavioral Scientist, 63(2): 186-207.

Banerjee, Payal. 2006. "Indian Information Technology Workers in the United States: The H-1B Visa, Flexible Production, and the Racialization of Labor." Critical Sociology 32(2-3).

Batalova, Jeanne. 2006. Skilled immigrant and native workers in the United States: the economic competition debate and beyond. E1 Paso, Texas: LFB Scholarly Publishing

Bauder, Harald. 2006. Labor movement: how migration regulates labor markets. Oxford University Press.

Bills, David, Valentina Di Stasio, and Klarita Gërxhani. 2017. "The Demand Side of Hiring: Employers in the Labor Market." Annual Review of Sociology 43: 291-310.

Binder, Amy, Daniel Davis, and Nick Bloom. 2016. "Career Funneling: How Elite Students Learn to Define and Desire "Prestigious" Jobs." Sociology of Education 89: 20-39.

Blau, Francine, and Lawrence Kahn. 2017. "The Gender Wage Gap: Extent, Trends, and Explanations." Journal of Economic Literature, 55 (3): 789-865.

Bhagwati, Jagdish and Milind Rao. 1999. "Foreign Students in Science and Engineering Ph.D. Pro- grams: An Alien Invasion or Brain Gain?" in B. Lindsay Lowell ed., Foreign Temporary Workers in America: Policies that Benefit the U.S. Economy Westport, CT: Quorum Books.

Bound, John, Murat Demirá, Gaurav Khanna, and Sarah Turner. 2015."Finishing Degrees and Finding Jobs: U.S. Higher Education and the Flow of Foreign IT Workers." Innovation Policy and the Economy 15(1): 27-72.

Boyd, Monica and Derrick Thomas. 2002. "Skilled Immigrant Labour: Country of Origin and the Occupational Locations of Male Engineers." Canadian Studies in Population 29(1):71-99.

Castells, Manuel. 2009. The rise of the network society. Wiley Press.

Chiswick, Barry. 1999. "Are Immigrants Favorably Self-Selected?" American Economic Review, 89 (2): 181-185.

Chiswick, Barry. 2011. High-skilled immigration in a global labor market, Washington, D.C.: AEI Press.

Clark, Ximena, Timothy J. Hatton, and Jeffrey G. Williamson. 2007. "Explaining U.S. Immigration, 1971-1998," The Review of Economics and Statistics, 89(2), 359-373.

Cornelius, Wayne, Thomas Espenshade and Idea Salehyan. 2001. The International Migration of the Highly Skilled. University of California, San Diego. 
Cotter, David, Joan Hermsen and Paula England. 2008. "Moms and jobs: trends in mothers' employment and which mothers stay home. American Families: a multicultural reader. 2nd ed. Stephanie Coontz (ed.), 379-86. New York: Routledge.

DiPrete, Thomas and Claudia Buchmann. 2013. The Rise of Women: The Growing Gender Gap in Education and What It Means for American Schools. New York: Russell Sage Foundation.

Elder, Glen. 1985. "Perspectives on the Life Course." In Life Course Dynamics: Trajectories and Transitions, 1968-1980, edited by G. H. Elder Jr, 23-49. Ithaca, NY: Cornell University Press.

England, Paula. "The Gender Revolution: Uneven and Stalled." Gender and Society 24, no. 2 (2010): 149-66.

Engzell, Per, and Mathieu Ichou. "Status Loss: The Burden of Positively Selected Immigrants.” International Migration Review 54, no. 2 (June 2020): 471-95.

Etzkowitz, Henry and Chunyan Zhou. 2017. The Triple Helix. London: Routledge.

Feliciano, Cynthia 2005. "Educational selectivity in U.S. Immigration: How do immigrants compare to those left behind?" Demography 42, 131-152.

Flippen, Chenoa A. and Emilio A. Parrado. 2015. "A Tale of Two Contexts: Mexican Women's Labor Force Participation in the United States and Mexico." International Migration Review 49: 232-259.

Gabriel, Paul and Schmitz, Susanne. 2007. "Gender differences in occupational distributions among workers." Monthly Labor Review. 19-24.

Glass, Jennifer, Sharon Sassler, Yael Levitte, and Kaherine Michelmore. 2013 "What's so special about STEM? A comparison of women's retention in STEM and professional occupations." Social Forces 92(2): 723-756.

Goldin, Claudia, Mitchell, Joshua. 2017. "The New Life Cycle of Women's Employment: Disappearing Humps, Sagging Middles, Expanding Tops.” Journal of Economic Perspectives 31(1):161-82.

Gonzales, Roberto. 2016. Lives in Limbo. Berkeley: University of California Press.

Granovetter Mark. 1995. Getting a Job: A Study of Contacts and Careers. Chicago: University of Chicago Press.

Grogger, Jeffrey and Gordon Hanson. 2013. "Attracting Talent: Location Choices of ForeignBorn PhDs in the US.” NBER Working Paper Series \#18780.

Hanson, Gordon, William Kerr and Sarah Turner (eds.) 2018. High-skilled migration to the United States and its economic consequences. Chicago: University of Chicago Press.

Hudson, Kenneth. 2007. The new labor market segmentation: Labor market dualism in the new economy. Social Science Research 36: 286-312.

Jacobs, Elizabeth. 2020a. Forthcoming. "The homogenizing and diversifying effects of migration policy in the internationalization of higher education." Higher Education.

Jacobs, Elizabeth. 2020b. Forthcoming. "Work visas and return migration: how migration policy shapes global talent." Journal of Ethnic and Migration Studies.

Jasso, Guillermina. 2009. Ethnicity and the immigration of highly skilled workers to the United States. Int. J. Manpower 30, 26-42.

Jasso, Guillermina. 2011. "Migration and stratification." Social Science Research 40 (5): 1292 1336. 
Kato, Takao, and Chad Sparber. 2013. "Quotas and Quality: The Effect of H-1B Visa Restrictions on the Pool of Prospective Undergraduate Students from Abroad." Review of Economics and Statistics 95(1): 109-126.

Kerr, Sari Pekkala, William Kerr, Çağlar Özden, and Christopher Parsons. 2016. "Global Talent Flows." The Journal of Economic Perspectives 30(4): 83-106.

Kõu, Anu and Ajay Bailey. 2014. "'Movement Is a Constant Feature in My Life': Contextualising Migration Processes of Highly Skilled Indians." Geoforum 52: 113-122.

Lesky, Linda, "Physician Migration to the United States and Canada: Criteria For Admission," in High-Skilled Immigration in a Global Labor Market, Barry Chiswick (ed.) (Washington, D.C., The AEI Press, 2011).

Levitt, Peggy and Nancy Glick Schiller. 2004. "Transnational perspectives on migration: conceptualizing simultaneity." International Migration Review 38(145):595-629.

Lin Nan 2001. "Building a network theory of social capital." Connections 22(1): 28-51.

Liu-Farrer, Gracia, Brenda Yeoh and Michiel Baas. 2020. "Social construction of skill: an analytical approach toward the question of skill in cross-border labour mobilities." Journal of Ethnic and Migration Studies 46(12): 1-15.

Lucas, Samuel. 2001. "Effectively maintained inequality: education transitions, track mobility, and social background effects." American Journal of Sociology. 106(6):1642-90.

Lutter, Mark. 2015. "Do Women Suffer from Network Closure?" American Sociological Review 80(2): 329-58.

Massey, Douglas and Ilana Redstone Akresh. 2006. "Immigrant Intentions and Mobility in a Global Economy: The Attitudes and Behavior of Recently Arrived U.S. Immigrants." Social Science Quarterly 87(5): 954-971.

Massey, Douglas. 1987. "Understanding Mexican Migration to the United States." Journal of Sociology 92(6):1372-1403.

Massey, Douglas and Felipe García España. 1987. "The Social Process of International Migration." Science 237(4816): 733-738.

Marsden, Peter and Elizabeth Gorman. 2001. "Social networks, job changes, and recruitment." In Sourcebook of Labor Markets, I. Berg and A. L. Kalleberg (eds). New York: Plenum Publishers.

McDonald James Ted, Casey Warman and Christopher Worswick, "Earnings, Occupations and Schooling Decisions of Immigrants with Medical Degrees: Evidence for Canada and the United States" in High-Skilled Immigration in a Global Labor Market, Barry Chiswick (ed.) (Washington, D.C., The AEI Press, 2011).

Mood, Carina. 2010. "Logistic Regression: Why We Cannot Do What We Think We Can Do, and What We Can Do About It." European Sociological Review 26(1): 67-82.

Munshi Kaivan and Mark Rosenzweig. 2006. "Traditional institutions meet the modern world: Caste, gender, and schooling choice in a globalizing economy." American Economic Review 96(4): 1225-1252.

Mustillo, Sarah, Omar Lizardo, and Rory McVeigh. 2018. "Editors' Comment: A Few Guidelines for Quantitative Submissions." American Sociological Review 83(6): 1281-83.

Obukhova, Elena and George Lan. 2012. "Do Job-Seekers Benefit from Contacts?” MIT Sloan Research Paper No. 4971-12.

Ong, Aihwa: Flexible Citizenship: The Cultural Logics of Transnationality (Duke Univ. Press: 1999) 
Özden, Çaglar. 2006. “Educated Migrants: is There Brain Waste?.” In International Migration, Remittances, and The Brain Drain, edited by Çaglar Özden and Maurice Schiff, 227-244. Washington, D.C.: The World Ban

Özden, Çaglar and David Phillips. 2015. "What really is brain drain? Location of birth, Education and Migration Dynamics of African Doctors." KNOMAD Working Paper \#4,

Parrado, Emilio. 2004. "International Migration and Men's Marriage in Western Mexico." Journal of Comparative Family Studies 35(1) 51-71.

Perlmann, Joel. 2007. Italians Then, Mexicans Now. New York: Russell Sage Foundation.

Portes, Alejandro and Min Zhou. 1993 "The New Second Generation: Segmented Assimilation and its Variants." ANNALS. 530(1):74-96.

Portes, Alejandro. 2003. "Conclusion: Theoretical Convergencies and Empirical Evidence in the Study of Immigrant Transnationalism," International Migration Review 37 (3): 874892.

Rivera, Lauren. 2012. "Hiring as Cultural Matching: the Case of Elite Professional Service Firms." American Sociological Review 77: 999-1022

Rosenzweig, Mark. 2008. "Higher Education and International Migration in Asia: Brain Circulation." In Annual World Bank Conference on Development Economics, Regional 2008: Higher Education and Development, edited by Justin Yifu Lin and Boris Pleskovic, 59-84. Washington, D.C.: World Bank.

Sassen, Saskia. 1991. The Global City, Princeton University Press.

Sassen, Saskia. 2007. A Sociology of Globalization. New York: Simon and Schuster.

Smith, Michael and Adrian Favell. The Human Face of Global Mobility, New Brunswick, New Jersey: Transaction Publishers, 2006

Stark, Oded and J. Edward Taylor. 1989. Relative Deprivation and International Migration. Demography 26: 1-14.

Torche, Florencia. 2011. "Is a college degree still the great equalizer?" American Journal of Sociology 117(3):763-807.

Vijaya, Ramya and Bidisha Biswas. 2019. Indian Immigrant Women and Work. Routledge.

Walton-Roberts, Margaret. 2020a. "Occupational (im)mobility in the global care economy." Journal of Ethnic and Migration Studies. 46 (16): 3441-3456

Waldinger, Roger. 2015. The Cross-Border Connection. Cambridge: Harvard University Press.

Walton-Roberts, Margaret. 2020b. "Intermediaries and transnational regimes of skill." Journal of Ethnic and Migration Studies 46(12): 1-18.

Wildavsky, Ben. 2010. The Great Brain Race: How Global Universities Are Reshaping the World, Princeton University Press.

Wimmer, Andreas, and Nancy Glick-Schiller. 2002. "Methodological Nationalism and Beyond." Global Networks 2 (4): 301-334.

Zeng, Zhen and Yu Xie. 2004. “Asian-Americans' Earnings Disadvantage Reexamined: The Role of Place of Education.” American Journal of Sociology 109 (5): 1075-1108. 


$\begin{array}{llll}\text { Table 1. Descriptive statistics of sample } & & \\ & \text { Full sample } & \begin{array}{l}\text { U.S. } \\ \text { Bachelor's }\end{array} & \begin{array}{l}\text { Indian } \\ \text { Bachelor's }\end{array} \\ \begin{array}{l}\text { Demographic background } \\ \text { Male }\end{array} & 69 \% & 61 \% & 73 \% \\ \text { Female } & 31 \% & 39 \% & 27 \% \\ \text { Average years in U.S. } & 8.8 & 12.7 & 6.7 \\ \text { Highest degree } & & & \\ \text { Bachelor's } & 18 \% & 31 \% & 3 \% \\ \text { Master's } & 65 \% & 57 \% & 84 \% \\ \text { Doctorate } & 17 \% & 15 \% & 13 \% \\ \text { Multinational educations } & & & \\ \text { Bachelor's only } & 16 \% & 33 \% & 7 \% \\ \text { U.S. Master's } & 59 \% & 52 \% & 64 \% \\ \text { Indian Master's } & 11 \% & 1 \% & 17 \% \\ \text { Work history } & & & \\ \text { Ever-worked in India } & 54 \% & 17 \% & 74 \% \\ \text { Ever-worked in U.S. } & 93 \% & 97 \% & 91 \% \\ \text { Ever-worked in other } & 18 \% & 16 \% & 19 \% \\ \text { Ever-worked in India and U.S. } & 48 \% & 15 \% & 66 \% \\ & \mathbf{( N = 7 , 1 7 7 )} & \mathbf{3 6 \%} & 64 \% \\ & & & \\ & & & \end{array}$


Table 2. Country at first job and current job by place of education and degree level

$\begin{array}{lllll} & \begin{array}{c}\text { United } \\ \text { States }\end{array} & \text { India } & \text { Other } & \text { Total } \\ \begin{array}{l}\text { First Job } \\ \text { U.S. Bachelor's }\end{array} & 86 \% & 8 \% & 6 \% & (\mathrm{~N}=2,556) \\ \text { Indian Bachelor's } & 24 \% & 68 \% & 8 \% & (\mathrm{~N}=4,621) \\ \text { Current Job } & & & & \\ \begin{array}{l}\text { Bachelor's } \\ \text { U.S. }\end{array} & 83 \% & 10 \% & 7 \% & (\mathrm{~N}=2,556) \\ \text { Indian } & 61 \% & 13 \% & 26 \% & (\mathrm{~N}=4,621) \\ & & & & \\ \begin{array}{l}\text { Master's } \\ \text { U.S. }\end{array} & 81 \% & 9 \% & 10 \% & (\mathrm{~N}=4,234) \\ \text { Indian } & 59 \% & 29 \% & 12 \% & (\mathrm{~N}=789) \\ \begin{array}{l}\text { Doctorate } \\ \text { U.S. }\end{array} & & & & \\ \text { Indian } & 87 \% & 5 \% & 8 \% & (\mathrm{~N}=1,021) \\ \begin{array}{l}5+y e a r s ~ s i n c e \\ \text { most recent degree }\end{array} & 57 \% & 25 \% & 18 \% & (\mathrm{~N}=98) \\ \begin{array}{l}\text { U.S. } \\ \text { Indian }\end{array} & 87 \% & 4 \% & 9 \% & (\mathrm{~N}=1,914) \\ & 58 \% & 31 \% & 11 \% & (\mathrm{~N}=3,615) \\ & & & & \end{array}$


Table 3. Coefficients from binary logistic regression models predicting first job in U.S. vs. India by country of education and degree level

Model $1 \quad$ Model 2

\begin{tabular}{|c|c|c|}
\hline \multicolumn{3}{|l|}{$\begin{array}{l}\text { Degree level and country at first job } \\
\text { (ref. Indian Bachelor's only) }\end{array}$} \\
\hline U.S. Bachelor's only & $3.017^{\star \star *}(.069)$ & $3.120^{\star \star \star}(.076)$ \\
\hline Indian Bachelor's U.S. advanced & $2.506^{\star \star \star}(.129)$ & $2.478^{\star * *}(.132)$ \\
\hline U.S. Bachelor's U.S. advanced & $3.135^{\star \star \star}(.263)$ & $3.170^{\star \star \star}(.270)$ \\
\hline Any Indian advanced & $0.228+(.140)$ & $0.310+(.163)$ \\
\hline $\begin{array}{l}\text { Highest degree at first job STEM } \\
\text { (ref. non-STEM) }\end{array}$ & & $0.189+(.097)$ \\
\hline \multicolumn{3}{|l|}{$\begin{array}{l}\text { Year of first job } \\
\text { (ref. pre-recession) }\end{array}$} \\
\hline $2008 / 2009$ & & $0.338^{\star \star \star}(.045)$ \\
\hline 2010 and later & & $0.412^{\star \star \star}(.074)$ \\
\hline Male & & $-0.022 \quad(.066)$ \\
\hline $\begin{array}{l}\text { Constant } \\
V=7.177 \\
V=0.001,{ }^{* *} p \leq 0.01,{ }^{*} p \leq 0.05,+p<.1\end{array}$ & $-1.301^{\star \star \star}(.037)$ & $-1.704^{\star \star \star}(.116)$ \\
\hline
\end{tabular}

Degree level and country at first job

(ref. Indian Bachelor's only)

Indian Bachelor's U.S. advanced

U.S. Bachelor's U.S. advanced

$3.135^{\star * \star}(.263)$

$3.170 * \star *(270)$

$0.189+(.097)$

Highest degree at first job STEM

Year of first job

(ref. pre-recession)

2008/2009

2010 and later

$-0.022(.066)$

${ }^{* \star} p \leq 0.001,{ }^{* *} p \leq 0.01,{ }^{*} p \leq 0.05,+p<.1$ 
Table 4. Coefficients from binary logistic regression models predicting current job in U.S. vs. India by country of education and degree level

\begin{tabular}{|c|c|c|}
\hline \multirow{2}{*}{\multicolumn{3}{|c|}{$\begin{array}{l}\text { Degree level and country } \\
\text { (ref. Indian Bachelor's only) }\end{array}$}} \\
\hline & & \\
\hline U.S. Bachelor's only & $1.110^{\star \star \star}(.122)$ & $0.961^{\star \star \star}(.125)$ \\
\hline Indian Bachelor's U.S. advanced & $1.102^{\star \star \star}(.079)$ & $1.007^{\star \star \star}(.087)$ \\
\hline U.S. Bachelor's U.S. advanced & $1.721^{\star * \star}(.114)$ & $1.671^{\star \star \star}(.115)$ \\
\hline Any Indian advanced & $-0.415^{\star \star \star}(.091)$ & $-0.476^{\star \star \star}(.095)$ \\
\hline $\begin{array}{l}\text { Highest degree STEM } \\
\text { (ref. non-STEM) }\end{array}$ & & $0.260^{\star \star \star}(.074)$ \\
\hline \multicolumn{3}{|l|}{$\begin{array}{l}\text { Graduation cohort of highest } \\
\text { degree (ref. pre-recession) }\end{array}$} \\
\hline Class of $2008 / 2009$ & & $0.099 \quad(.080)$ \\
\hline Class of 2010 and later & & $0.255^{\star \star \star}(.079)$ \\
\hline Male & & $-0.236^{\star \star \star}(.072)$ \\
\hline Constant & $0.681^{\star \star *}(.068)$ & $0.650^{\star \star \star}(.100)$ \\
\hline
\end{tabular}


Appendix.

Table A1. Coefficients from binary logistic regression models predicting first job in U.S. vs. India by country of advanced degree (Indian Bachelor's graduates)

$$
\text { Model } 1 \quad \text { Model } 2
$$

Degree level and country at first job

(ref. Indian Bachelor's only)

Indian Bachelor's U.S. advanced

$2.518^{\star \star \star}(.129) \quad 2.413^{\star \star \star}(.131)$

Indian Bachelor's Indian advanced

$0.181 \quad(.143)$

$0.063(.145)$

Highest degree at first job STEM

$0.274^{\star \star \star}(.083)$

(ref. non-STEM)

Year of first job

(ref. pre-recession)

2008/2009

2010 and later

$-0.326^{\star \star \star}(.086)$

$-0.595^{\star \star \star}(.088)$

Male

$0.070 \quad(.082)$

Constant

${ }^{* * *} p \leq 0.001,{ }^{* *} p \leq 0.01,{ }^{*} p \leq 0.05,+p<.1$

$-1.311^{* * *}(.039) \quad-1.281^{* * *}(.102)$

$\mathrm{N}=4,621$ 
Table A2. Coefficients from binary logistic regression models predicting first job in U.S. vs. India by country of advanced degree (U.S. Bachelor's graduates)

Degree level and country at first job Model $1 \quad$ Model 2

(ref. U.S. Bachelor's only)

U.S. Bachelor's U.S. advanced

$0.625^{\star}(.260) \quad 0.542^{\star} \quad(.263)$

U.S. Bachelor's Indian advanced

$-1.586^{\star \star}(.559)$

$-1.581^{\star *}(.564)$

Highest degree at first job STEM

(ref. non-STEM)

$0.112 \quad(.114)$

Year of first job

(ref. pre-recession)

2008/2009

2010 and later

$0.033 \quad(.161)$

Male

$-0.418^{\star *}(.146)$

Constant

$-0.340^{\star *}(.120)$

${ }^{\star * *} p \leq 0.001,{ }^{* *} p \leq 0.01,{ }^{*} p \leq 0.05,+p<.1$

$-1.740^{\star \star \star}(.058) \quad 2.086^{\star \star \star}(.155)$

$\mathrm{N}=2,556$ 
Table B. Coefficients from Linear Probability OLS regression models predicting first job in U.S. vs. India by country of education and degree level

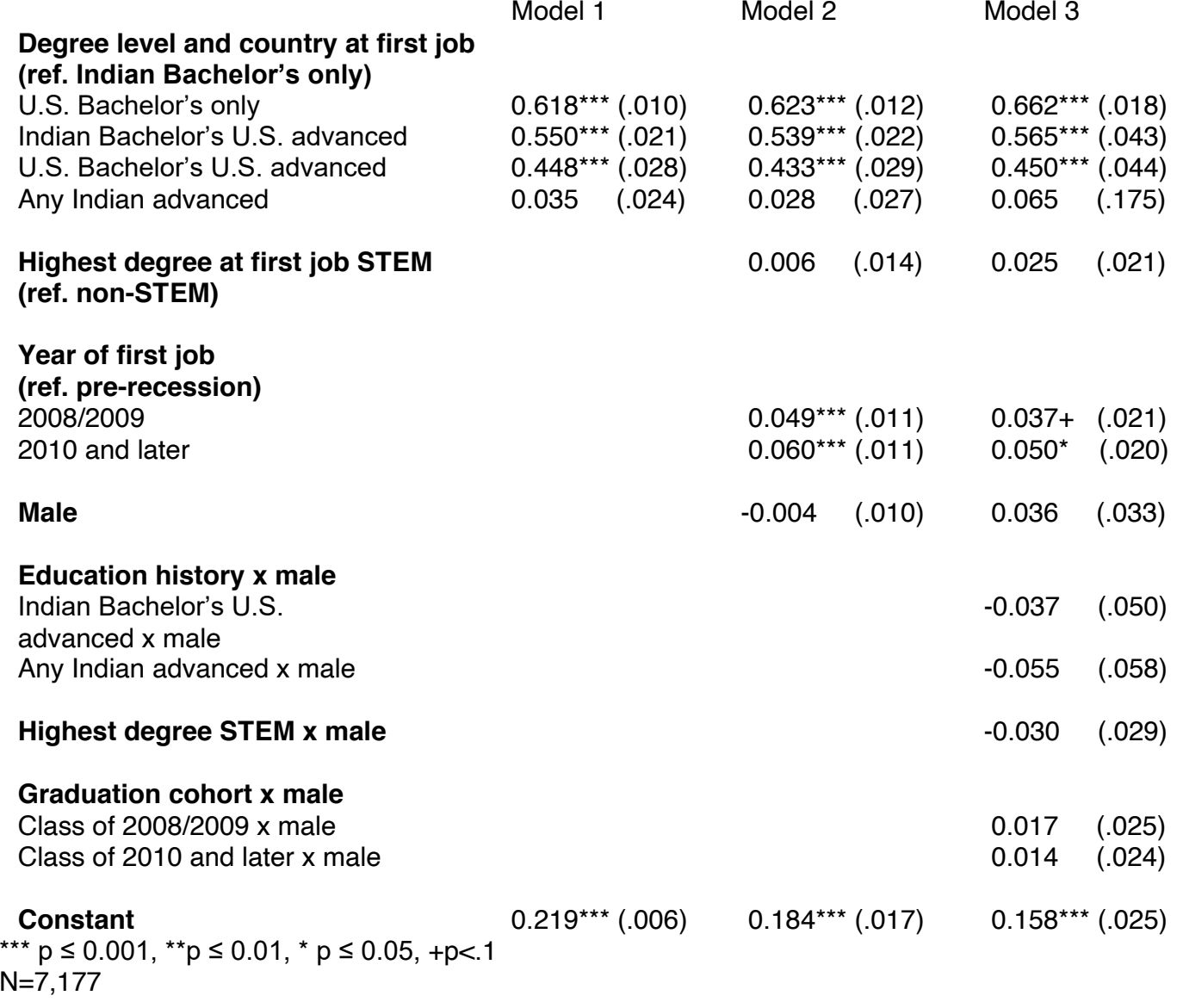


Table C1. Coefficients from binary logistic regression models predicting current job in U.S. vs. India by country of advanced degree (Indian Bachelor's graduates)

\begin{tabular}{|c|c|c|}
\hline & Model 1 & Model 2 \\
\hline \multicolumn{3}{|l|}{$\begin{array}{l}\text { Degree level and country } \\
\text { (ref. Indian Bachelor's only) }\end{array}$} \\
\hline Indian Bachelor's U.S. advanced & $1.097^{\star \star \star}(.083)$ & $0.946^{\star * \star}(.098)$ \\
\hline Indian Bachelor's Indian advanced & $-0.410^{\star * *}(.095)$ & $-0.546^{* * *}(.102)$ \\
\hline $\begin{array}{l}\text { Highest degree STEM } \\
\text { (ref. non-STEM) }\end{array}$ & & $0.242^{\star \star} \quad(.091)$ \\
\hline \multicolumn{3}{|l|}{$\begin{array}{l}\text { Graduation cohort of highest } \\
\text { degree (ref. pre-recession) }\end{array}$} \\
\hline Class of $2008 / 2009$ & & $-0.478^{\star \star} \quad(.092)$ \\
\hline Class of 2010 and later & & $-0.031^{\star \star \star}(.145)$ \\
\hline Male & & $-0.139 \quad(.087)$ \\
\hline Ever-worked India & & $-1.029^{\star \star \star}(.107)$ \\
\hline Constant & $0.686^{\star \star \star}(.074)$ & $1.677^{\star \star \star}(.174)$ \\
\hline
\end{tabular}

$N=4,621$ 
Table C2. Coefficients from binary logistic regression models predicting current job in U.S. vs. India by country of advanced degree (U.S. Bachelor's graduates)

Model 1

Degree level and country

(ref. U.S. Bachelor's only)

U.S. Bachelor's U.S. advanced

U.S. Bachelor's Indian advanced

Highest degree STEM

(ref. non-STEM)

Graduation cohort of highest

degree (ref. pre-recession)

Class of $2008 / 2009$

Class of 2010 and later

Male

$0.859^{\star \star \star}(.124)$

$-1.329^{\star \star}(.337)$

Model 2

Constant

${ }^{\star \star \star *} p \leq 0.001,{ }^{\star \star} p \leq 0.01,{ }^{*} p \leq 0.05,+p<.1$

$1.552^{\star \star \star}(.085)$

$\mathrm{N}=2,556$

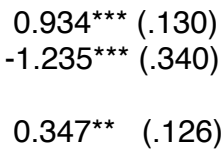




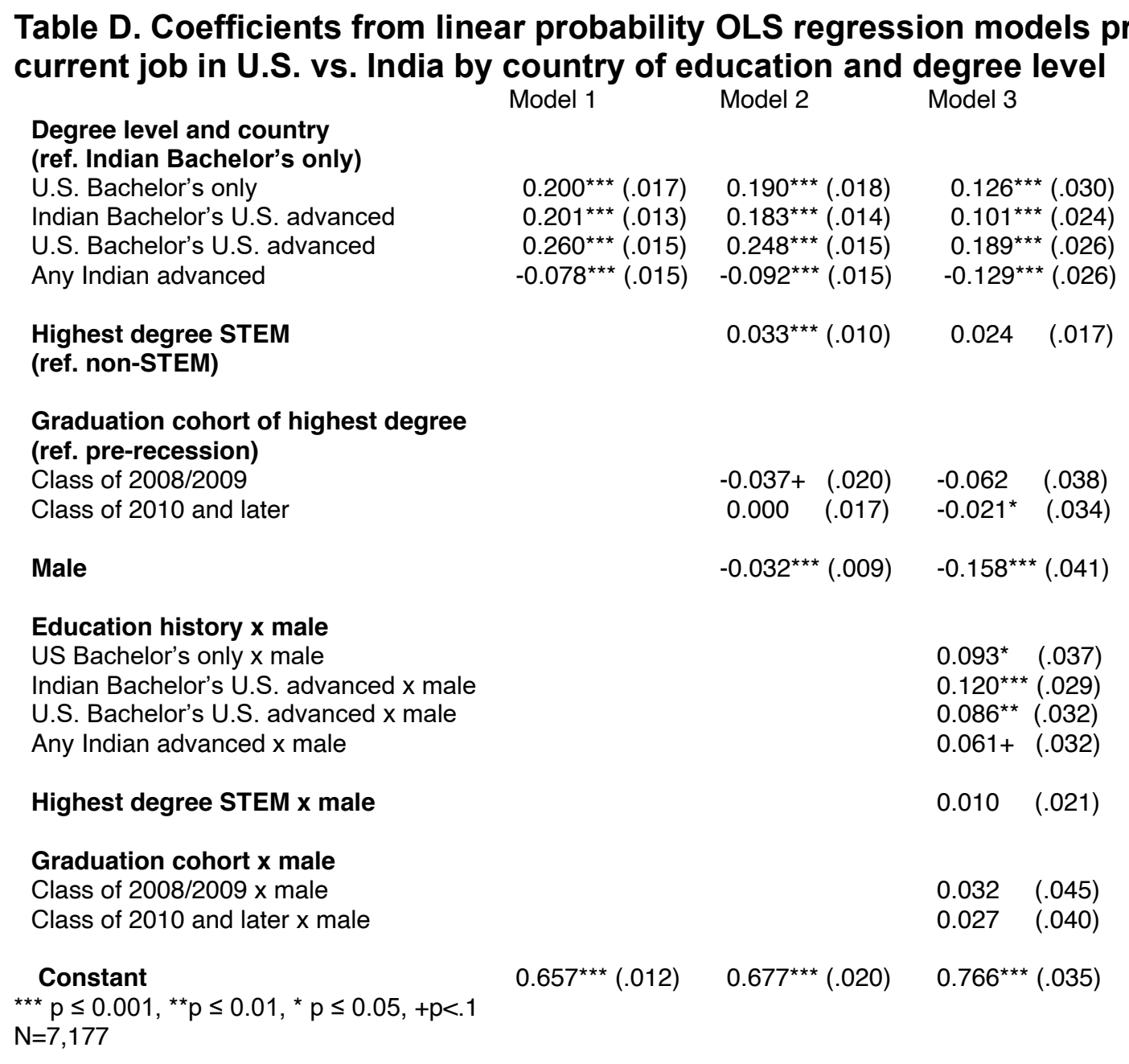




\section{Table E. Comparison of ever-migrants on Linkedln with traditional sources}

\begin{tabular}{|c|c|c|c|c|c|}
\hline & $\begin{array}{l}\text { Ever- } \\
\text { migrants } \\
\text { (Linkedln) }\end{array}$ & $\begin{array}{l}\text { Graduates of } \\
\text { Indian } \\
\text { Universities } \\
\text { (AISHE) }\end{array}$ & $\begin{array}{l}\text { Currently } \\
\text { enrolled U.S. } \\
\text { Int'I students } \\
\text { (ICE) }\end{array}$ & $\begin{array}{l}\text { OFLC Labor } \\
\text { certification } \\
\text { statistics }\end{array}$ & $\begin{array}{l}\text { Ever-migrants } \\
\text { currently in } \\
\text { U.S. (Linkedln) }\end{array}$ \\
\hline \multicolumn{6}{|l|}{$\begin{array}{l}\text { Demographic } \\
\text { background }\end{array}$} \\
\hline Male & $69 \%$ & $55 \%$ & $57 \%$ & Not reported & $69 \%$ \\
\hline Female & $31 \%$ & $45 \%$ & $43 \%$ & Not reported & $31 \%$ \\
\hline $\begin{array}{l}\text { Years since most } \\
\text { recent degree }\end{array}$ & 6.8 & $\mathrm{n} / \mathrm{a}$ & $\mathrm{n} / \mathrm{a}$ & 20.6 & 6.6 \\
\hline \multicolumn{6}{|l|}{ Highest degree } \\
\hline Bachelor's & $18 \%$ & $80 \%$ & $38 \%$ & $44 \%$ & $18 \%$ \\
\hline Master's & $65 \%$ & $19 \%$ & $41 \%$ & $55 \%$ & $65 \%$ \\
\hline Doctorate & $17 \%$ & $1 \%$ & $8 \%$ & $1 \%$ & $17 \%$ \\
\hline $\begin{array}{l}\text { Ever-studied in } \\
\text { USA }\end{array}$ & $81 \%$ & Not captured & $100 \%$ & Not captured & $89 \%$ \\
\hline \multicolumn{6}{|l|}{ Work history } \\
\hline $\begin{array}{l}\text { Currently working } \\
\text { in India }\end{array}$ & $9 \%$ & Not captured & Not captured & $0 \%$ & $0 \%$ \\
\hline $\begin{array}{l}\text { Currently working } \\
\text { in USA }\end{array}$ & $83 \%$ & Not captured & Not captured & $100 \%$ & $100 \%$ \\
\hline $\begin{array}{l}\text { Currently working } \\
\text { in other }\end{array}$ & $8 \%$ & Not captured & Not captured & $0 \%$ & $0 \%$ \\
\hline $\begin{array}{l}\text { Ever-worked in } \\
\text { India }\end{array}$ & $54 \%$ & Not captured & Not captured & Not captured & $47 \%$ \\
\hline $\begin{array}{l}\text { Ever-worked in } \\
\text { USA }\end{array}$ & $93 \%$ & Not captured & Not captured & Not captured & $100 \%$ \\
\hline $\begin{array}{l}\text { Ever-worked in } \\
\text { other }\end{array}$ & $18 \%$ & Not captured & Not captured & Not captured & $9 \%$ \\
\hline \multirow[t]{2}{*}{$\begin{array}{l}\text { Ever-worked in } \\
\text { India and USA }\end{array}$} & $48 \%$ & Not captured & Not captured & Not captured & $48 \%$ \\
\hline & $(\mathrm{N}=7,177)$ & $(\mathrm{N}=30,200,000)$ & $\begin{array}{l}(\mathbf{N}=364,000) \\
{ }^{*} \text { Indian citizens } \\
\text { comprise } 18 \%\end{array}$ & $(\mathrm{~N}=39,677)$ & $(\mathrm{N}=5,922)$ \\
\hline
\end{tabular}

Source: All India Survey of Higher Education (2010); U.S. Immigration and Customs Enforcement 2010; Department of Labor OFLC Public Disclosure Data 2018 
Figure 1. Dynamic migration flows and life-course transitions

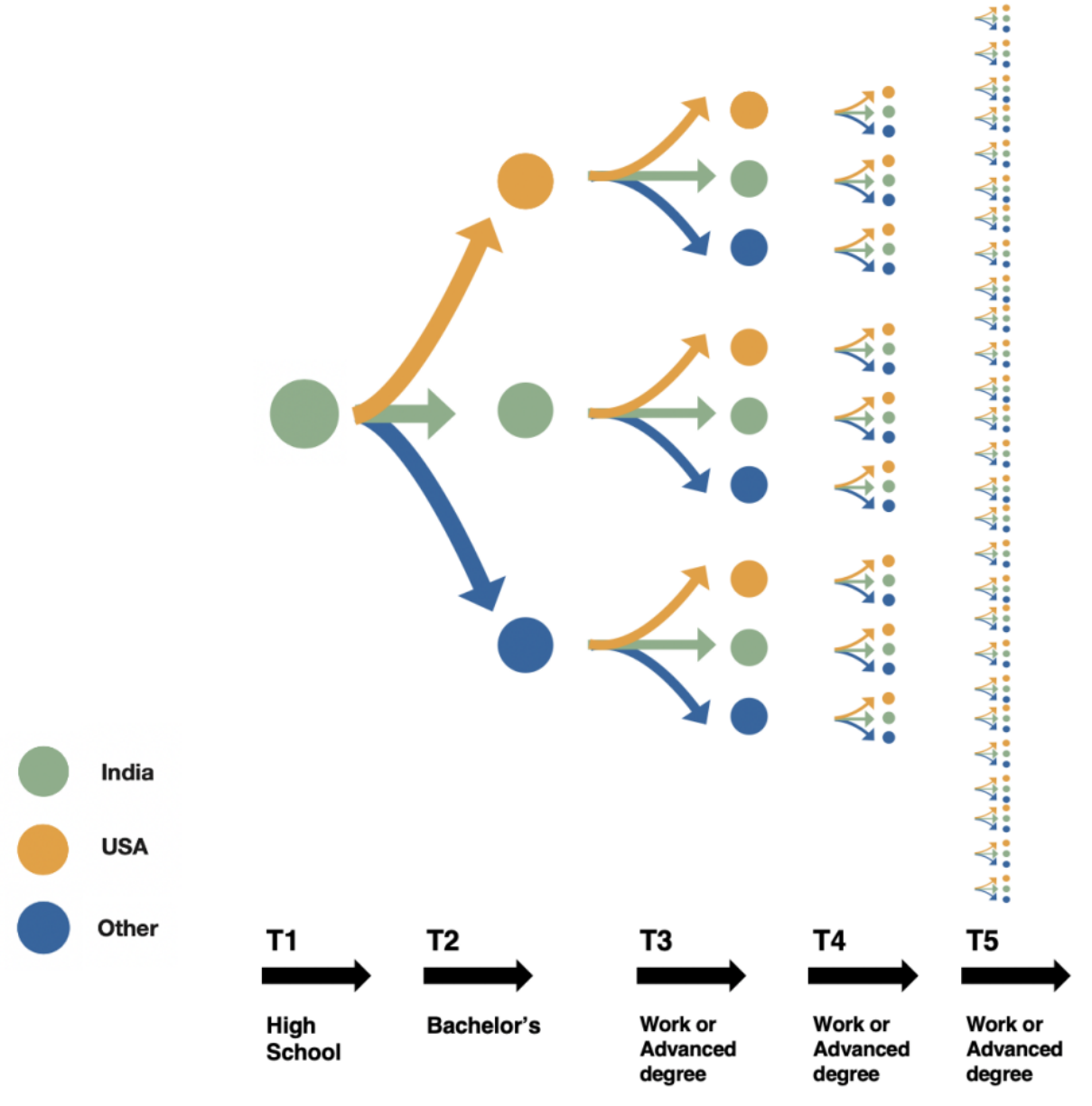

Typology of migrant pathways of entry and exit

Student migrant

Bachelor's

Advanced
Labor migrant

Individual recruit

Subcontracting transfer

Multinational transfer
Return migrant

Student

Labor 


\section{METHODOLOGICAL APPENDIX}

This study uses a unique combination of original employment history data and in-depth interviews with skilled migrants to understand the process of skill and knowledge development in the international system of higher education and the global labor market. Pairing these two data sources, which were developed and designed in concert with each other, offers breadth and depth as I explore longitudinal migration trends among skilled migrants and unpack several substantive factors driving those patterns.

\section{Nature of the dataset}

While the transnational employment history data offers an exciting new approach to following migrants across countries and time, it comes with some limitations. LinkedIn is widely used in both the United States and India, but is not representative of the entire population, and membership is not random. The population may be biased towards individuals actively seeking jobs and might miss unemployed individuals and there may be non-random selection out of the labor force due to issues like lacking work authorization, discrimination, gender and family dynamics. The LinkedIn-based sampling strategy employed in this project is not able to observe these dynamics, but the targeted interview design specifically seeking out people in these populations aims to address some of these limitations from an in-depth qualitative perspective.

The nature of the self-reported information on the website may be somewhat unreliable. Workers may exaggerate work experience or exclude periods of unemployment -- to avoid reporting gaps employment on their resumé, sometimes individuals extend the duration of a job for longer than they actually held it. In other cases, they may omit work experience not relevant to their current field, or work experience in a foreign country. Finally, membership is concentrated in certain industries, like information technology; I focus on these industries precisely for this reason, but it does not allow me to systematically analyze the entire field of skilled migration in other industries, like higher education, where LinkedIn is less commonly used.

As new technologies have generated an explosion in data generated by social media, cell phones and mobile apps, population scientists are beginning to develop tools and methods to harness the potential of big data for social scientific research. It has incredible potential for understanding human movement and migration behavior to develop new methodologies using digital trace data to produce estimates of demographic migrant flows. Previous research has shown that biases can be modeled and filtered out using statistical approaches, in particular when social media data can be calibrated with data from representative surveys (Yildiz et al. 2017; Zagheni et al. 2014, 2017).

\section{Data design and calibration}

The population of 7,177 ever-migrants, defined as anyone who studied or worked in the United States for more than six months, was randomly sampled from the full population of Indian-citizen alumni of top-ranked U.S. and Indian universities who earned their Bachelor's degree between 2005 and 2012. The sample of ever-migrants allows me to examine migration across the life-course and exploit variation in permanent settlement outcomes, with a focus on return migration versus migrants currently in the United States (despite issues with rightcensoring and return, for the purposes of this analysis, I conceptualize migrants currently in the U.S. as more "permanent").

I examine the quality and coverage of the LinkedIn data in measuring migration characteristics, while contrasting this data with other nationally representative sources that have 
been used in previous work on these topics. I calibrate the data generated in this study with four surveys, the All-India Survey of Higher Education (AISHE), U.S. Immigration and Customs Enforcement data on international students in the United States, PERM Disclosure data from the Department of Labor and data from the American Community Survey. The All-India Survey of Higher Education includes all graduates of Indian universities but does not include information on whether they eventually migrated to the U.S. The U.S. ICE data on international students surveys all currently enrolled foreign-born students in the United States on student visas, but does not provide detailed analysis at the level of nationality (Indian students make up $18 \%$ of the total international student population in the U.S.). I look at these two datasets from 2010 to compare the same Bachelor's cohort as the LinkedIn sample. The OFLC PERM disclosure data includes migrants applying for employer-sponsored permanent residency; thus, this sample only includes migrants currently working on a visa in the United States who plans to settle permanently in the U.S. It excludes those who have or plan to return to India, as well as those on non-work visas, like student or family visas. I look at this dataset from 2018 the most recent full year of data of migrants in the labor market at the time of survey collection.

Table E compares key characteristics across data sources. This table compares the demographic background, education and work history of ever-migrants in this study to graduates of Indian universities and international students in the United States. Indian citizens make up about 18 percent of the international student population in the U.S.; ICE data is not available by individual nationality. As reported in Table E, 69\% of ever-migrants in the present study are male, slightly higher than the 55 percent and 57 percent of Indian university graduates and U.S. international students. The Department of Labor PERM data does not collect information on gender. Further, $82 \%$ of ever-migrants hold an advanced degree, while only $19 \%$ of Indian university graduates, $41 \%$ of U.S. international students and $56 \%$ of migrants applying for employer-sponsored green cards do the same do the same.

I test the extent to which ever-migrants in the LinkedIn sample differ in educational attainment from students and workers in the survey data using chi-square analysis. A chi-square test indicates that ever-migrants in the LinkedIn sample significantly differ from the groups captured in the survey data at the $p<.001$ level. This evidence is consistent with the notion that the transnational data design in the employment history data captures a distinct migrant population by including both immigrants settling in the U.S. permanently and return migrants who leave as students or workers.

I then restrict this sample to migrants currently in the U.S. to adjust for selectivity in the return migrant population relative to the permanent settlement population. A similar chi-square test of difference in educational attainment between the LinkedIn sample, ICE data and OFLC data indicates that the sample of ever-migrants currently in the U.S. is still significantly different at the $\mathrm{p}<.001$ level, with ever-migrants in the LinkedIn sample having higher levels of educational attainment. The higher proportion of advanced degree attainment among migrants in the LinkedIn data can be attributed to the difference in years since most recent degree - the mean years since most recent degree for migrants in the OFLC data is 20.6, while the mean years for ever-migrants in the U.S. is 6.6. Educational attainment has increased significantly in India in this period with the expansion of higher education, helping to explain this gap (Chakravorty, Kapur and Singh 2016).

These survey data provide useful comparative context to the sample designed for this study, but also illustrate many of the limitations of cross-sectional and nationally-bounded surveys discussed in the literature review. The differences in educational attainment between the populations in these samples can be attributed to migrant educational selectivity and cohort 
differences. We would expect to see a significantly more highly educated population of skilled migrants, compared to non-migrant Indian university graduates, international students who may not have completed their schooling, or earlier cohorts of Indian migrants to the U.S. Skilled labor migration policy that can lead to credential inflation further explains the gap in advanced degrees between skilled migrants and international students (Feliciano 2005; Van Hook et al. 2020; Author 2020b). Further, as Table E illustrates and as I discuss in the literature review, the employment histories analyzed in this paper capture a number of key phenomena related to transnational migration that cross-sectional and nationally bounded surveys are not able to observe.

\section{Variable construction}

Indian citizenship was coded using logical imputation. Indian citizens were identified by those who fit two simultaneous criteria: listing fluency in Hindi on their profile page and listing an Indian high school for secondary studies. This is an imperfect measure, as it misses individuals who do not include Hindi on their profiles. However, because resumés are constructed to showcase as many skills and abilities as possible, it is likely that most people will report language fluency on their LinkedIn profile page. Further, there is not a perfect correlation between Hindi speakers and Indian citizens: with this filter alone, I might select non-Indian citizen Hindi speakers (such as U.S.-born Indian Americans who speak Hindi at home), and might miss some non-Hindi speaking Indian citizens. However, Hindi is the official national language of only India and offers the strongest filter available on LinkedIn to identify Indian citizens. Though recent Indian migration associated with the tech industry has been concentrated in South India, where Telugu and Tamil are spoken, I do not include other Indian dialects like Tamil or Telugu because this might also capture Tamil speakers from other countries like Sri Lanka (Chakravorty, Kapur and Singh 2016). I include Indian high school as a further check on citizenship status, as Indian high schools have very few international students and thus there is a close correlation between attendance at an Indian high school and Indian citizenship. Further, this controls for early educational institutional context, sorting out Indian citizens who attended high school abroad. These measures have been validated in the interview data.

I code country of a migrant's education using the name of the school listed on a user's profile and then matched with the city and country where the school was located. By definition, non-migrants in the sample do not have any U.S. education because migrating to the United States to study would make them an education migrant. The sample drew on migrants with Bachelor's degrees from U.S. and Indian schools, but a small portion of the sample had advanced degrees from other countries like the United Kingdom, Australia or Germany. Among all people with a Master's degree, 5.6 percent had a Master's degree from other countries; among the sample holding a Doctorate degree, 5.3 percent had a Doctorate from a country other than India or the United States. As noted in the descriptive statistics of migrant employment histories, 65 percent of the total sample held a Master's degree from a U.S. or Indian University (Table 2 in manuscript).

I use location data embedded in employment entries to develop migration histories. This offers a new way to study migration behavior, but there is some slippage in this approach. First, some people work remotely, and the location of their company's headquarters does not reflect where they live (this sample was collected in 2019, well before the COVID-19 pandemic, but the messy dynamics of location and remote work have become clear in this period). This is primarily an issue at the most granular locational levels like city; this approach largely accurately measures the country where a migrant works, as validated in interviews. 
Second, this measure is conditional on labor force participation and might bias estimates in non-random patterns. For example, as Banerjee (2019) has shown, skilled women migrants on H-4 spousal dependent visas are systematically excluded from the U.S. labor force because the visa does not authorize paid work. This might bias the LinkedIn sample towards more female employment in the United States than is reflected in the full migrant population, but might also underestimate the full population of skilled migrant women settling in the United States.

Finally, there are some complexities in the location data reported on LinkedIn job entries. Ninety-nine percent of job entries in the sample automatically included current location information, and 81 percent of job entries for subsequent jobs included information location. I coded missing data by hand. Most entries included city and state information; for these entries, I added country-level information. In cases where no location information was reported, I used the company name to look up the location of the headquarters.

After employing this strategy, 15 percent of job postings had ambiguous location information. For example, Tata Consultancy Services and IBM are multinational corporations and employ significant numbers of people in both the United States, India, and internationally. In these cases, I coded country information based on the timing of the job in relation to the country of the previous location information. Thus, if someone listed a job at Tata Consultancy Services in 2008 with missing location information, but reported other jobs in Bangalore, India in 2007 and 2009, I filled in India as the country information for the posting with missing information. This thus produces a conservative estimate of migration, as I am biasing the sample towards nonmigration in cases where there may in fact be a short migration spell. In an analysis of selfreported data compared to the more complete data that I hand-coded, the estimate only changes four percent.

I used the International Standard Classification of Education (ICSED) to code majors into field of study and sort these into STEM- and non-STEM fields. I harmonized degrees between Indian and U.S. universities to address small structural differences in degrees conferred. For example, Indian universities offer a Masters of Technology (MTech) which provides training in fields specifically related to technology, in addition to the Master of Science and Master of Engineering degrees offered at U.S. schools. A Master of Science (MS) typically is more academic and research oriented, while a Master of Engineering (ME) is a more professional degree and provides more applied training in areas like mechanical, electrical and chemical engineering. Other Master's programs offer degrees in other fields like a Master of Business Administration (MBA), Master of Arts (MA), Master of Laws (LLM) or Master of Commerce (MComm).

I use migrant profile names and pictures to code gender in a dichotomous variable "male." This approach relies on external assessments of gender presentation because Linked-In profiles do not self-report gender, conflating gender identity and presentation and reinforcing the notion of a gender binary. Because the primary questions about gender explored in this dissertation engage how migrants interact with state and corporate institutions that largely reinforce external assessments of gender and the gendered presentation of self in professional settings. Further qualitative analysis of gender identity and migration at work would enrich previous work showing that gender identity and presentation can play out in complex ways in the workplace (Schilt 2011). 